\title{
How Can We Better Understand, Identify, and Support Highly Gifted and Profoundly Gifted Students? A Literature Review of the Psychological Development of Highly-Profoundly Gifted Individuals and Overexcitabilities
}

\author{
Vanessa R Wood $^{1 *}$ and Krystyna C Laycraft ${ }^{2}$ \\ ${ }^{1}$ The International Gifted Consortium (IGC), Research Center for the Highly-Profoundly Gifted, Scottsdale, USA \\ ${ }^{2}$ The Center for Chaos Studies, Nanton, Alberta, Canada
}

\begin{abstract}
Heightened sensitivity, heightened intensity, heightened awareness and advanced cognitive development, compared to chronological aged peers, distinguish the highly-profoundly gifted child and permeate their social, emotional, physical, cognitive and/or altruistic life experiences. This instinctive and often asynchronous development has been historically misunderstood, misidentified, and misdiagnosed by professionals who have not received training on the unique characteristics, behaviors, and development typical of this population. As a result, the natural development and potential of highly-profoundly gifted children and adolescents are vulnerable and at high risk. A review of the literature found the characteristics, behaviors and developmental markers of the highly-profoundly gifted strikingly similar to the characteristics, behaviors and development of the combination of multiple, higher-level overexcitabilities. Further study of overexcitabilities and Dabrowski's human development theory found the combination of multiple, higher-level overexcitabilities distinctively different than individual overexcitabilities. Developmental dynamisms explained the multi-faceted development of multiple overexcitabilities at the highest level. It was concluded that multiple, higherlevel overexcitabilities and the development of dynamisms correlate closely with the heightened sensitivity, heightened intensity, heightened awareness and advanced cognitive development of highly-profoundly gifted children and adolescents and therefore could be an effective tool for identification. Additional research and further development of assessment tools to identify higher-level overexcitabilities, developmental dynamisms and highly-profoundly gifted students are warranted. Education outreach and professional development are recommended for parents, teachers, school administrators, counselors, psychologists, pediatricians and policy makers to curve misunderstanding, misidentification and misdiagnosis. Mandates to appropriately identify and support the education and development of highly-profoundly gifted children and adolescents, are imperative.
\end{abstract}

\section{Keywords}

Over-excitabilities, Overexcitabilities, Profoundly gifted, Highly gifted, Gifted, Dabrowski

\section{Introduction}

Terman, Hollingworth, and Gross [1-3], pioneers in the field of the gifted, studied the development of children with an unusually high intelligence quotient (IQ). They found that these children exhibited significant differences in social, emotional, physical, and altruistic development, in addition to the significant difference in cognitive ability, compared to their moderately gifted age-mates. Whether giftedness is identified through inborn nature or outward achievement, or a combination of the two, it can be viewed ultimately as a degree of experience on the continuum of human development. Indicating advanced and accelerated development,
*Corresponding author: Vanessa R Wood, The International Gifted Consortium (IGC), Research Center for The Highly-Profoundly Gifted, 14362 N. Frank Lloyd Wright Blvd, Suite 1000, Scottsdale, AZ, 85260, USA

Accepted: August 13, 2020

Published online: August 15, 2020

Citation: Wood VR, Laycraft KC (2020) How Can We Better Understand, Identify, and Support Highly Gifted and Profoundly Gifted Students? A Literature Review of the Psychological Development of Highly-Profoundly Gifted Individuals and Overexcitabilities. Ann Cogn Sci 4(1):143-165 
Citation: Wood VR, Laycraft KC (2020) How Can We Better Understand, Identify, and Support Highly Gifted and Profoundly Gifted Students? A Literature Review of the Psychological Development of Highly-Profoundly Gifted Individuals and Overexcitabilities. Ann Cogn Sci 4(1):143-165

giftedness includes heightened physical sensing, emotions, cognition, and intuition (The Thomas B. Fordham Institute) [4]. At its core, this seemingly naturally accelerated process of growth, sparked by unique biology, produces greater-than-typical neurological responses, behaviors, and abilities. These traits, which appear to be propelled by heightened sensitivity, intensity, and awareness, are the underpinnings of gifted development or what Dabrowski [5] referred to as overexcitabilities that resemble the hallmark characteristics, behaviors, and development of the highly-profoundly gifted population.

In a recent meta-analysis of 16 studies of overexcitabilities and giftedness, Steenbergen-Hu [6] found that giftedness was significantly correlated with all five areas of overexcitabilities (psychomotor, sensual, intellectual, imaginational and emotional). In addition, Steenbergen-Hu [6] was the first to report positive correlations between the presence of overexcitabilities and the level of giftedness. These findings suggest the greatest correlations exist between overexcitabilities and the highly-profoundly gifted population (those in the top 99.9 percentile, the highest level of giftedness, or those with an IQ of 145+).

\section{The problem}

Many highly-profoundly gifted children are being overlooked in our school systems. Currently, children are being identified as gifted by their teachers who typically have little or no training in giftedness. Without the teachers having an appropriate understanding of the characteristics, behaviors, and needs of highly-profoundly gifted students, these children often go unidentified as such. As a result, the development and/or developmental potential of this population is vulnerable and at high risk. Highly-profoundly gifted children are often misunderstood, misidentified, and misdiagnosed, not only by teachers and school administrators, but also by counselors, psychologists, and pediatricians who have had no training in recognizing the unique social, emotional, physical, cognitive, and altruistic characteristics, behaviors, and development typical of this population [7].

\section{The question}

Given the prevalence of misunderstanding, misidentification, and misdiagnosis of the highly-profoundly gifted population [7] and the most recent meta-analysis suggesting a potential correlation between overexcitabilities and the level of giftedness [6], could the assessment of overexcitabilities be an effective tool for identifying the distinguishing characteristics, behaviors, and development of highly or profoundly gifted students?

To consider this question, we conducted a literature review to (1) Evaluate the existing literature on highly- profoundly gifted children and that on overexcitabilities, (2) Tease out the characteristics, behaviors, and development of each, and (3) Recognize correlations and consider the assessment of overexcitabilities as a tool for identifying the distinguishing characteristics, behaviors, and development of highly-profoundly gifted students.

\section{Methodology}

Landmark studies by Terman, Hollingworth, and Gross [1-3] uncovered the unique, interconnected, developmental synergy within the highly-profoundly gifted population. Each recognized the vital importance of studying the whole child for the education, and well-being of the highly-profoundly gifted. Therefore, the framework of this review was established based on the documented characteristics, behaviors, developmental mile-stones, and life experiences of the highly-profoundly gifted child. The literature review results and discussion are organized by social, emotional, physical, cognitive, and altruistic areas of development.

To begin, a historical literature review of the highly-profoundly gifted population focusing on characteristics, behaviors, and development was conducted, as well as a historical review of the literature on overexcitabilities, with the same focus. Targeted disciplines for both reviews were the same, and included research in psychology, education, and human development; however, the scope of the search was not limited only to these fields. Research data bases were searched using applicable key search terms including: Gifted, highly gifted, profoundly gifted, overexcitabilities, Kazimierz Dabrowski, Theory of Positive Disintegration. Peer-reviewed articles and books were used to gather historical data from the 1900's to present 2019.

Next, the characteristics, behaviors, developmental markers, and life experiences of the highly-profoundly gifted were gathered from longitudinal studies specific to this population in addition to other clinical documentations, and case studies by credentialed professionals in the field. Similarly, the characteristics, behaviors, and development of the five forms of overexcitabilities-psychomotor, sensual, imaginational, intellectual and emotional-were also identified alongside the theory of development from which overexcitabilities originated.

Since no studies of overexcitabilities and the highly-profoundly gifted population (individuals with an unusually high IQ defined as $145+$ in this literature review or three standard deviations above the mean) were found in the literature, studies of overexcitabilities and gifted individuals (generally IQ 130+ or two standard deviations above the mean) and the identification of giftedness were used in this review.

Lastly, the correlations were identified using a holistic approach organized by social, emotional, physical, cognitive and altruistic areas of development and synthesized based on the literature review question: Could the assessment of overexcitabilities be an effective tool for identifying the distinguishing characteristics, behaviors, and development of highly and profoundly gifted students? Additional questions and new correlations were noted throughout the review, and recommendations for further research are suggested.

\section{The Literature Review-Part I}

\section{The highly-profoundly gifted-history and defini- tions}

Landmark studies: Terman [1] established the term gifted 
Citation: Wood VR, Laycraft KC (2020) How Can We Better Understand, Identify, and Support Highly Gifted and Profoundly Gifted Students? A Literature Review of the Psychological Development of Highly-Profoundly Gifted Individuals and Overexcitabilities. Ann Cogn Sci 4(1):143-165

in one of the most influential psychological studies to date, Genetic Studies of Genius. Revising the Simon-Binet scale, Terman developed the Stanford-Binet Intelligence Scales. His study focused on the characteristics, educational needs, and physical well-being of children with superior ability. Fascinated by the outliers, Terman's contemporary, Hollingworth studied the extremities of the population for 23 years until her untimely death in 1939. She was the first to identify the importance of nurturing the gifted child's social-emotional development [8]. Hollingworth advocated for "the whole child," emphasizing the integration of the mind, body, and soul, and not the consideration of the intellect on its own.

Gross's 20-year longitudinal study is the most in-depth investigation of highly-profoundly gifted children. Of the 60 children studied, Gross [3] recorded in depth the intellectual and social-emotional development of 15 highly-profoundly gifted children. Her observations documented the harsh realities of the school experiences of the profoundly gifted.

While each chose their own terminology, it is important to recognize that Terman, Hollingworth, and Gross essentially studied the same population - the profoundly gifted (criteria for classification from Davidson Institute). Terman referred to his study participants as "termites" or "geniuses." Hollingworth studied "children above 180 IQ" and Gross studied the "exceptionally gifted" or children with an IQ of 160+. In this literature review, we combine and refer to this population as the highly-profoundly gifted and refer to The Davidson Institute's quantitative measure of $145+1 \mathrm{IQ}$.

Lack of a universal definition and mandated criteria for identification: Levels of giftedness and the criterion for identifying the highly-profoundly gifted have varied by as much as 25 IQ points [9]. Historically, the confusion has stemmed from a lack of universal criteria for distinguishing and quantitative scores for the highly-profoundly gifted [10]. A child's characteristics and behaviors are the manifestations of intelligence [11]; therefore, their characteristics, behaviors, and development should guide the identification of the highly-profoundly gifted child. If criteria, including definitions and quantitative descriptors, are federally mandated for children with intellectual disabilities, the same should exist for children with highly-profoundly developed intellects [12].

Following the groundbreaking work of Terman and Hollingworth, the first federal definition, the Marland Report [13], acknowledged giftedness as the expression of specific abilities or aptitudes. The specific criteria for identification of gifted students were not mandated and the distinguishing characteristics, behaviors, and development of highly-profoundly gifted students were not acknowledged. Interpretation and identification were left to individual states, school administrators, and classroom teachers who historically have little or no training in giftedness. In addition, Gallagher and Gallagher (1994, cited in Kristiansen-Hagne, [14], p.7) recognized that "the challenging, inquisitive nature of the highly intelligent or extremely creative student is usually less appreciated by teachers than the bright student who achieves well."

As a result, the identification of giftedness became simply the identification of the top $3-5 \%$ of academic achievers or as deemed by individual school districts. The qualitative, identifying characteristics, behaviors and development of giftedness, based on research and exhibited by highly-profoundly gifted children, were not included. Psychomotor ability was removed in 1978, but the rest of the federal definition of giftedness has remained unchanged since its inception in 1972 [15]. The distinct differences of the highly-profoundly gifted have seemingly been ignored [16].

Quantitative identification through the private sector: Above-level testing: Following Hollingworth's lead, Stanley (1979) created the Center for Talented Youth (CTY) and identified "precocious youth" through above-level testing at Johns Hopkins University. "He certainly understood and respected that tests had their limits and could never capture the whole child, but he also believed strongly that tests could and did provide rich and valid information that had academic relevance" (Colangelo, para. 2) [17]. Benbow and Lubinski from Vanderbilt University continued Stanley's longitudinal Study of Exceptional Talent (SET). Follow-up studies have focused on the students' adult careers and accomplishments [18-20]. Stanley and the Center for Talented Youth identified tools and provided programs to better serve students who demonstrated exceptional cognitive abilities.

Overexcitabilities introduced as distinguishing qualitative characteristics: At the same time, microbiologist and psychologist, Michael M Piechowski [21] introduced overex-citabilities as distinguishing characteristics of giftedness and development. Piechowski and his mentor Kazimierz Dabrowski, creator of the theory of positive disintegration (1972) identified overexcitabilties as greater-than-typical internal and external neurological responses to stimuli. However, overexcitabilities were not incorporated in the federal or state descriptions or qualities of gifted students.

Lack of federal funding for the highly-profoundly gifted: The Jacob K Javits Gifted and Talented Students Education Act [22], the only federally funded program for gifted students, earmarked federal dollars for programs supporting special and diverse populations. Like the Mar-land Report [13], the Act identified gifted and talented students as those who demonstrate evidence of high performance (Jacob K. Javits Gifted and Talented Students Education Act [22]). The research on the characteristics, behaviors, and development of the highly-profoundly gifted were not included. Terman, Hollingworth, and Gross uncovered and identified the unique social, emotional, physical, cognitive, and altruistic development and potential of profound giftedness because they recognized the interconnected relationships associated with advanced cognition [23]. Cognitive abilities were certainly identified in some; however, the larger foundation of giftedness-exceptional, holistic development, and/or extraordinary potential-established in longitudinal studies were overlooked or not supported.

Qualitative definitions of giftedness: In 1991, the Columbus Group was the first to formally define the qualitative features, differences, and development of giftedness, including heightened intensity, inner experiences, awareness, vulnerability and asynchronous development. The National Associ- 
Citation: Wood VR, Laycraft KC (2020) How Can We Better Understand, Identify, and Support Highly Gifted and Profoundly Gifted Students? A Literature Review of the Psychological Development of Highly-Profoundly Gifted Individuals and Overexcitabilities. Ann Cogn Sci 4(1):143-165

ation for Gifted Children (NAGC) [24] defined asynchronous development as the mismatch between cognitive, emotional, and physical development of gifted individuals. Gifted children often have significant variations within themselves and develop unevenly across skill levels (National Association for Gifted Children, n.d.) [25]. Clark's [26] definition of giftedness was the first to include biological roots, advanced and accelerated development, and the affective physical sensing and/or intuitive development of giftedness, in addition to advanced cognitive abilities.
Most recent quantitative and qualitative definitions of the profoundly gifted: In 1999, in recognition and support of profoundly gifted students and their families, Bob and Jan Davidson started the Davidson Institute for Talent Development, a not-for-profit organization based in Reno, Nevada. The Davidson Institute defined the profoundly gifted as those scoring at the $99.9^{\text {th }}$ percentile on IQ and achievement tests (Davidson Institute, 2019).

In 2015, the International Gifted Consortium (IGC), Re-

Table 1: Historical definitions and identification that influenced the understanding of profound giftedness.

\begin{tabular}{|c|c|c|}
\hline Historical influences & Terminology & Definitions and identification \\
\hline Terman [1] & Gifted Genius & $\begin{array}{l}\text { Revised the Simon-Binet and developed the Stanford-Binet; studied 1,528 } \\
\text { participants with IQ of } 140+\text { on the Stanford-Binet scale }\end{array}$ \\
\hline Hollingworth [2] & Children above $180 \mathrm{IQ}$ & $\begin{array}{l}\text { Identified (12) children with IQ of } 180+\text { on the Stanford-Binet intelligence } \\
\text { scales and tracked their development; findings published in her book, } \\
\text { Children Above } 180 \text { IQ: Origin and Development by her husband Harry } \\
\text { Hollingworth in } 1942 \text { [2]. }\end{array}$ \\
\hline Marland Report [13] & Giftedness & $\begin{array}{l}\text { Six areas of giftedness: General intellectual ability, specific academic } \\
\text { aptitude, creative or productive thinking, leadership ability, visual and } \\
\text { performing arts ability, and psychomotor ability. }\end{array}$ \\
\hline Stanley & Precocious youth & $\begin{array}{l}\text { Identified gifted students } 13 \text { years or younger through a score of } 700 \text { or } \\
\text { greater on the mathematics section, and later the reading section, of the SAT. }\end{array}$ \\
\hline Piechowski [21] & Gifted & $\begin{array}{l}\text { Identified psychomotor, sensual, intellectual, imaginational, and emotional } \\
\text { overexcitabilities and develop-mental potential in gifted individuals }\end{array}$ \\
\hline $\begin{array}{l}\text { Jacob Javits Gifted } \\
\text { and Talented Students } \\
\text { Act }[22]\end{array}$ & $\begin{array}{l}\text { Disadvantaged } \\
\text { gifted and talented } \\
\text { students }\end{array}$ & $\begin{array}{l}\text { Demonstrate high performance capability in areas such as intellectual, } \\
\text { creative, artistic, or leadership capacity, or in specific academic fields (Jacob } \\
\text { Javits Gifted and Talented Students Act, 1988) [22]. }\end{array}$ \\
\hline Columbus Group & Giftedness & $\begin{array}{l}\text { Asynchronous development in which advanced cognitive abilities and } \\
\text { heightened intensity combine to create inner experiences and awareness } \\
\text { that are qualitatively different from the norm; asynchrony increases with } \\
\text { higher intellectual capacity, and the uniqueness of the gifted renders them } \\
\text { particularly vulnerable, requiring modifications in parenting, } \\
\text { teaching, and counseling in order for them to develop optimally (Morelock, } \\
\text { p.3) [69]. }\end{array}$ \\
\hline Gross $[3,36]$ & Exceptionally gifted & $\begin{array}{l}20 \text {-year longitudinal study of } 60 \text { children with IQ of } 160+\text {; published findings } \\
\text { for } 15 \text { children in Exceptionally Gifted Children }\end{array}$ \\
\hline $\begin{array}{l}\text { Davidson Institute for } \\
\text { Talent Development }\end{array}$ & Profoundly gifted & Those scoring in the 99th percentile of IQ and achievement tests; IQ $=145+$ \\
\hline Clark [26] & Giftedness & $\begin{array}{l}\text { Giftedness is a biologically rooted concept that is the result of a high level } \\
\text { of integration and acceleration among the neural cells within the brain. The } \\
\text { level of intelligence and the structure and process of thinking and learning } \\
\text { change, becoming more complex, accelerated, and indepth. Giftedness may } \\
\text { be developed and expressed to a moderate, high, or profound level (Clark, } \\
\text { p.56) [26] }\end{array}$ \\
\hline $\begin{array}{l}\text { IGC, Research Center } \\
\text { for Highly-Profoundly } \\
\text { Gifted [27] }\end{array}$ & $\begin{array}{l}\text { Highly-Profoundly } \\
\text { gifted }\end{array}$ & $\begin{array}{l}\text { Profound giftedness is significantly advanced cognitive abilities and } \\
\text { development, as compared to those of peers in the chronological age group, } \\
\text { experienced through heightened sensitivity, intensity, and awareness } \\
\text { identifiable through social, emotional, physical, cognitive, and/or altruistic } \\
\text { behaviors, developmental milestones, and life experiences across the } \\
\text { lifespan. This intuitive, and often asynchronous, human development is at } \\
\text { high risk of misunderstanding, misidentification, and misdiagnosis (the 3Ms), } \\
\text { and requires support and scaffolding from like-minded peers, mentors, and } \\
\text { practitioners to meet the profoundly gifted individual's exceptionally unique } \\
\text { educational and developmental needs, and to provide fitting opportunities } \\
\text { for positive growth and well-being (IGC, Research Center for The Highly- } \\
\text { Profoundly Gifted, based on the works of Terman, Hollingworth, Columbus } \\
\text { Group, Clark, Gross, Dabrowski \& Piechowski, Webb, et al.) }[1-3,7,27,80] \text {. }\end{array}$ \\
\hline
\end{tabular}


Citation: Wood VR, Laycraft KC (2020) How Can We Better Understand, Identify, and Support Highly Gifted and Profoundly Gifted Students? A Literature Review of the Psychological Development of Highly-Profoundly Gifted Individuals and Overexcitabilities. Ann Cogn Sci 4(1):143-165

search Center for the Highly-Profoundly Gifted-the first research center dedicated to examining giftedness through the eyes of the highly-profoundly gifted-was established in Scottsdale, Arizona. As a 501c3, not-for-profit organization, the IGC embarked on a literature review, international collaboration, and education outreach to collaboratively better understand, identify, and support the unique social, emotional, physical, cognitive, and altruistic development of giftedness through the lens of the highly and profoundly gifted. Based on the collective works of pioneers and those who continue to take an interest in the profoundly gifted population [1-3,7] the IGC, Research Center for the Highly-Profoundly Gifted recognized the distinctive social, emotional, physical, cognitive and/or altruistic experience of the profoundly gifted [27] (Table 1).

For the purpose of this literature review, the terms highly gifted and profoundly gifted have been combined. The term highly-profoundly gifted denotes an IQ score of 145+ and represents the profoundly gifted population throughout this manuscript.

Profoundly gifted are distinctly different from even their moderately gifted peers: It is essential to realize that the profoundly gifted are as different from the moderately gifted as the moderately gifted are from the intellectually disabled [2]. The highly-profoundly gifted exhibit a higher degree of ability, energy, and level of intensity in most of the traits that are identified with giftedness [26]. Reference Clark [26] for a table of characteristics. Additionally, refer to Schultz [10] for a set of characteristics of profound giftedness. Gross [28] provided an in-depth view of the distinctions between giftedness and profound giftedness. Excerpts from her work describing a gifted student and a profoundly gifted student are given in Table 2.
Being able to perceive the differences in these two excerpts is an essential exercise for understanding the distinguishing characteristics, behaviors, development and needs of highly-profoundly gifted children.

\section{Literature Review Results: Distinctive Social, Emotional, Physical, Cognitive, and Altruistic Characteristics, Behaviors, and Development}

Developmental differences are the foundation of unusual intelligence [29]. Overall, the highly-profoundly gifted display radical differences from the developmental milestones observable in age-peers of aver-age ability [3]. Jessica, spoke early at 8 months, rarely stopped, and was described as being "electrically charged." She exhibited an astonishing attention span, a desire for harder work, and loved the challenge of the accelerated language program. She reported feeling like an alien and feelings of self-doubt, and was acutely embarrassed if reprimanded in front of other people [3]. Early on, Jessica exhibited greater-than-typical sensitivity, intensity, awareness, and asynchronous development.

As stated in the introduction of this literature review, it is imperative to realize that profoundly gifted children are profoundly different from even their moderately gifted agepeers [3]. Educationally, curriculum and programs developed for gifted learners are not sufficient for the exceptional needs of the profoundly gifted. An equally important fact is that the social and emotional development of profoundly gifted children differs and coincides with their advanced cognitive abilities [3].

Table 2: Distinctions between giftedness and profound giftedness: Excerpts from Gross [28].

\section{Distinctions between giftedness and profound giftedness}

Paula is a happy successful student, popular with her classmates and appreciated by her teachers. Her teachers readily acknowledge her abilities, even if they find it difficult to respond with appropriate curriculum interventions. Paula learned to read before her $5^{\text {th }}$ birthday. Now at age 9 , she has the reading abilities of a 12 -year-old and shows a definite talent for math problem solving. Although she prefers the companionship of children two or three years older, she is not "different" enough to be rejected by her classmates. Aware that Paula is highly able, the school arranged for her to be tested in $1^{\text {st }}$ grade, and her IQ was assessed at 133. Children of IQ 133 appear in the population at a ratio of approximately 1:40. (Gross, p.5) [28].

Alex taught himself to read, write, and count before age 3. By age 3 he had read The Lion, the Witch and the Wardrobe and was entranced by the world of Narnia, the relationships between the characters, and the battle between good and evil. "By the time he entered school, he was capable of $4^{\text {th }}$ grade math and was reading The Hobbit, which his teacher promptly took from him, stating that he should not be looking at his older brother's books as they would give him nightmares. Alex has no older brother, but he was so bemused by the teacher's comment that he lost the opportunity to tell her this. The most important lesson Alex learned in his first few weeks at school was that it would teach him nothing that he did not already know. His teacher insisted that he work through the reading readiness program with the rest of the class and placed him on a math program which involved recognizing the numbers 1 through 10 . He was so astonished that he complied without protest.

The compliance did not last long, however. In $2^{\text {nd }}$ and $3^{\text {rd }}$ grades he was angry, frustrated, and rebellious and made life difficult for himself, his teachers, and his classmates. Finally, to the relief of his teacher, his protests ceased. Alex is now in $6^{\text {th }}$ grade. Most of the time he is apathetic and withdrawn. He refuses to complete the simplistic and repetitive work that is presented to him, and because of this, nothing in the way of enrichment or extension is offered to him. His teachers are quite unaware that he has developed an expertise in Nordic mythology, which underpins the "middle earth" works of Tolkien. A professor of literature at the local university has called this expertise "astounding." Alex relates happily to the undergraduate students his professor friend has introduced to him, but at school he is a social outcast. The other children reject him because his speech, his interests, and the way he thinks are so different from theirs that there is virtually no point of contact between them. In $2^{\text {nd }}$ grade Alex's parents had him tested by a private psychologist who assessed his IQ at 169. Alex attends the same school as Paula, but ironically, because he does not display "gifted behavior" in class, he was not selected for the math pullout program. Indeed, his teacher refused to accept the psychologist's report, saying that she "did not believe in IQ tests and that there were several students in Alex's class who were much brighter. Children of IQ 169 appear in the population at a ratio of less than 1:100,000 (Gross, p. 6) [28]. 
Citation: Wood VR, Laycraft KC (2020) How Can We Better Understand, Identify, and Support Highly Gifted and Profoundly Gifted Students? A Literature Review of the Psychological Development of Highly-Profoundly Gifted Individuals and Overexcitabilities. Ann Cogn Sci 4(1):143-165

\section{Social development}

In 1930, Burks, Williams and Terman [30] concluded that "The exceptionally gifted child has one of the most difficult problems of social adjustment that any human being is ever called upon to meet" (cited in Gross, [3] p.16).

Radical acceleration and asynchronous development: While research supports positive outcomes of radical acceleration to fulfill the needs of highly-profoundly gifted students, their potential asynchronous development, or scatter in development, can also play a significant role. For instance, Hollingworth [2] described the experience of a 12-year-old boy attending college and his out-of-sync feelings: Intellectually a college student, but chronologically a 12-year-old. This life experience highlights the asynchronous development typical of highly-profoundly gifted children.

Lack of like-minded peers: Hollingworth [2] noted a range of social behaviors, from opposition and defiance to a lack of care or indifference, and the extreme difficulty the highly-profoundly gifted faced in forming friendships, most often due to the absence of like-minded peers. Common interests, vocabulary and experiences are necessary to bond friendships. Highly gifted children tend to have stronger, more memorable reactions to stimuli and experiences than their peers [31,32]. The highly-profoundly gifted children that seemed the most socially adept were identified early, and had parents and educational personnel seeking out resources to support their development [2].

Sheldon's [33] study of 28 children under 12 years with IQ $170+$ on the Stanford-Binet scale documented feelings of isolation and rejection in nearly half of the children. Janos [34] expanded on this research and found that the higher the level of giftedness, the higher the feeling of isolation and the more the child seemed to lack motivation to develop their intellectual talents. Janos's [34] comparative study of 32 profoundly gifted children and 40 moderately gifted children found significant differences in the profoundly gifted with the most obvious being the absence of a peer group with whom to relate [3]. Shaklee [35] noted that highly-profoundly gifted children appeared to be in tune with their differences, and intentionally acted "less gifted" around their age-mates.

Underachievement and social alienation: Many of the children in Gross's [3] study deliberately underachieved for peer acceptance. The more highly gifted the child, the greater the social pressure to conform or "dumb-down" his or her achievements, thoughts, or behaviors [12,28,36-38]. For example, Gross [3] reported Anastasia being called melodramatic; the child recounted feeling fake, lonely, and unhappy. While she felt a sense of pride in her own work, her heightened sense of awareness made her acknowledge that she could not express her happiness; Anastasia realized that pride in one's academic success was not socially acceptable.

Gross's [36] study found that more than $70 \%$ of early readers changed their reading habits or stopped reading altogether at school. This was the case for Roshni, when at 3 years, she received the universal message that children that age did not read and that it was wrong. In a follow-up study, Gross [3] documented Roshni's feelings of alienation; she was the only one who could read, besides the teacher. Roshni was atypical, "out-of-sync" compared to her chronological age peers.

The social rejection and isolation experienced by the highly-profoundly gifted are not due to their advanced development or abilities, but rather due to society's response to them (Neihart \& National Association for Gifted Children) [39]. Gross reported that Roshni was bored, lonely, and depressed. She was bullied by her peers, and, worse, she was teased by her teacher. In Gross's follow-up study, she divulged, "If I hadn't accelerated, I would have suffocated" [3].

Schools for highly-profoundly gifted children: Ideally, as Hollingworth [2] discovered, "when exceptionally gifted children who have been rejected by age peers are removed from the inappropriate grade placement and are permitted to work and play with intellectual peers, the loneliness and social isolation disappears and the child is accepted as a valued classmate and friend $[2,3]$. This was the case for those children fortunate enough to be identified and invited to attend the Speyer School in New York City, the first school for the highly-profoundly gifted, created and run by Hollingworth, the "birthmother of PG" [8].

Today, several schools exist across the United States for children who are identified as profoundly gifted, including the Davidson Academy at the University of Nevada, the Robinson Center at the University of Washington, Program for the Exceptionally Gifted at Mary Baldwin University, and the Gary K. Herberger Young Scholars Academy at Arizona State University. Virtual schools also exist. Potts [40] reported the desire for additional social opportunities in her case study of profoundly gifted students' experience in virtual classrooms [40].

\section{Emotional development}

Terman, Hollingworth, and Gross [1-3] realized that advanced cognition was not solely the result of advanced cognitive abilities but rather of the interconnected relationship between all areas of development. The emotional development of the highly-profoundly gifted exemplifies the core of giftedness [41]. While emotional needs are essentially the same across the continuum of development, the difference lies in the intensity propelling the development [42]. Hollingworth [2] and later Silverman [43] and Lovecky [44] all documented accelerated or "advanced" social-emotional development in their studies of profoundly gifted children.

Sensitivity and intensity: Emotional sensitivity and emotional intensity are the most distinctive descriptors of the highly gifted [45-47]. Heightened sensitivity embodies an array of inputs, including discernment, response, feelings, and display of emotions, aesthetics, and sensitivity to others [41]. Significantly greater-than-typical sensitivity allows the highly-profoundly gifted to intensely perceive nuances of that which the average person would not even be aware [3]. Roeper [48] described this greater-than-typical phenomenon as "a greater awareness, a greater sensitivity, and a greater ability to understand and transform perceptions into intellectual and emotional experiences" (p. 21).

Complexity: "Highly gifted children perceive the world 
Citation: Wood VR, Laycraft KC (2020) How Can We Better Understand, Identify, and Support Highly Gifted and Profoundly Gifted Students? A Literature Review of the Psychological Development of Highly-Profoundly Gifted Individuals and Overexcitabilities. Ann Cogn Sci 4(1):143-165

complexly, with access to a reality that is usually not reflected in the perceptions of those around them. Highly gifted children often lack access to an understanding or appreciative audience and they are unlikely to be able to exchange perceptions with others" [49]. The "intrapsychic complexities" as identified by Jackson and Peterson [50] are the intricate weaving of advanced cognitive abilities and asynchrony.

Acute awareness: The highly-profoundly gifted exhibit acute awareness from an early age. At birth and in their first year, documented accounts include leaps in developmental milestones including alertness, recognition, and movement $[2,3,50]$. They are acutely aware of their feelings of being different $[3,12,39]$. The more gifted the individuals, the more they tend to deviate from the norm [41]. Piechowski [51] explains this significantly greater-than-typical awareness as introspective-emotional. In his study of gifted adolescents, an introspective-emotional is described as one who is conscious of feelings, asks extensional questions of oneself, and understands his/her true self [51].

Saricam and Sahin [52] studied the environmental awareness and attitude of 154 highly gifted and 157 typical children aged 13-14 years. Using the Curiosity and Exploration Inventory-II (CEI), the Environmental Scale (EAS), and the Environmental Attitudes Scale (EAS), they found that the highly gifted scored higher than the typical children on all measures. Environmental awareness in highly gifted children increased as their curiosity and exploration increased. This is an influential study in support of the historical clinical observations of environmental awareness in highly gifted children. The heightened sensitivity and intensity and high intelligence of the developing highly-profoundly gifted child give way to heightened awareness [51]. The results of this study imply that the profoundly gifted have the highest potential for environmental awareness.

Acute awareness can be a double-edged sword. The ability to physically perceive all that surrounds them provides access to a plethora of information; likewise, possessing the ability to see and feel things that others cannot amplifies the differences between a highly gifted child and the majority of their gifted age-peers. This experience can have a depressing and demotivating effect on the highly-profoundly gifted child. Gross [3] acknowledged this painful reality by documenting the children's keen awareness. For example, Sally reported, "teachers had no idea what to do with me" (Gross, p. 252) [3]. Rufus realized his teachers' ongoing resentment when he was continually overlooked for awards, stating "I am being punished for doing too well" (Gross, p. 238) [3]. Rick, too, was well aware of his teachers' resentment of him for his grade acceleration in mathematics. He described his heightened awareness as being different than everyone else's; he was directed by a strong sense of right and wrong, and was guided by his independence to follow what he felt was true. At 16 years, Fred's friends were 19 and 20. His value system was significantly out-of-sync with his chronological-age peers. Fred described how he was attacked and berated for being different; the school principal described Fred as "emotionally mature" [3].
Feeling out-of-sync: The experiences documented from longitudinal studies to-date are typical for highly-profoundly children. Developing highly-profoundly gifted children can feel out-of-sync, not only within themselves or around their peers, but also with the world. Being "too different," being themselves can be "too much." Going undercover or masking their giftedness may be their best defense or protective coping mechanism [29].

Underachievement and vulnerability: Some highly-profoundly gifted children attempt to flee their giftedness altogether, resulting in under-achievement. Whitmore [53], Tannenbaum [54], reported low self-esteem and self-concept directly related to underachievement. In addition to underachievement, gifted children's social-emotional well-being may be more vulnerable due to their differences and heightened responses. According to Silverman [23], the greater the asynchrony, the greater the vulnerability. Neihart, et al. [39] suggested that highly-profoundly gifted children may be significantly more vulnerable and potentially at higher risk for maladjustment than typical children if their differences are not understood, acknowledged, and supported.

Piechowski [55] and Jackson [31] both documented case studies of highly gifted adolescents who experienced depression coupled with the ability to mask even the most severe symptoms. In an environment where they did not feel safe or appreciated, they might have used their abilities to camouflage and protect rather than to share and engage. These coping mechanisms, including underachievement, may lead to negative self-concept.

No studies exist that compare the occurrence of depression in highly-profoundly gifted children and their peers. Experienced counselors and psychologists working directly with highly-profoundly gifted children tend to believe that the likelihood of depression and suicide ideation is greater in this population than even among their moderately gifted peers; however, research specific to the highly-profoundly gifted population is needed to substantiate these clinical claims.

Underachievement is often the result of opposing, multifaceted, lived experiences, including the need to belong coupled with feeling different, extreme empathy coupled with helplessness, feelings of isolation, rejection, perfectionism, and the internal strive to always do what is right [26].

Introspection and introversion: Through extensive clinical work with the highly-profoundly gifted population, Mahoney [56] recognized the highly gifted's acute awareness as potentially their best coping mechanism. Citing the Gifted Identity Model and the stages of validation, affirmation, affiliation, and affinity, Mahoney observed that growth and development were ignited by the development of acute self-identity awareness and understanding [56]. This introspective awareness is characteristic of introversion.

Highly-profoundly gifted children have a tendency toward introversion $[31,43]$. The highly gifted embody a colorful inner life, weaving together the intellect, feelings, and abstract ideas. They tend to contemplate and fully process first before discussing with others [31]. 
Citation: Wood VR, Laycraft KC (2020) How Can We Better Understand, Identify, and Support Highly Gifted and Profoundly Gifted Students? A Literature Review of the Psychological Development of Highly-Profoundly Gifted Individuals and Overexcitabilities. Ann Cogn Sci 4(1):143-165

\section{Physical development}

Various indications of advanced, accelerated, and asynchronous physical and physiological development of highly and profoundly gifted children have been studied. Silverman [8] reported a familial link and documented that siblings are generally within $10 \mathrm{IQ}$ points. The human neurological system has a genetic basis [57].

Advanced psychomotor development: Terman [1] was the first to report advanced psychomotor development; compared to the average, the children in his study walked one month earlier. In Gross's [36] study, the children all walked before 12 months of age, more than 3 months earlier than the developmental milestone average of 15 months. In a national study of 725 highly gifted children, Vaivre-Douret [58] found advanced cephalocaudal axial neuromotor development in the first two years of life. These children rapidly acquired coordination and more independent movement, or posturo-locomotor acquisition, one to two standard deviations or one to two months earlier than the norm.

Advanced brain development: Alexander, et al. [59] conducted a comparative study of the brain using EEG. They compared the results of three groups: Gifted 13-year-olds, average 13 -year-olds, and 20-year-old college students. Their findings suggested that the brain activity of the mathematically gifted 13-year-olds was similar to that of the 20-yearold brain, thereby suggesting advanced brain development in mathematically gifted children [59]. O'Boyle [60] also studied the advanced physiology of the brains of mathematically gifted children (ages 10-15, scoring in the $99^{\text {th }}$ percentile on the mathematics section of the SAT). He found advanced development of the right hemisphere allowing for a unique form of "functional bilateralism" that significantly contributed to the collaborative drive of cognition and respective behavior. The interhemispheric communication and relationship (hypothesized as a function of the corpus callosum, increased grey:white matter ratio, or glia:neuron ratio), which is responsible for connecting the two hemispheres of the brain, were advanced. He also found greater-than-typical brain engagement, similar to that of or surpassing an adult brain. These findings suggest advanced development and processing abilities likely to be the product of a highly efficient operating system [60].

Laycraft [61] found advanced brain development corresponding to that identified in comparative studies of gifted adolescents. Advanced development was evident in the reorganization of neural networks resulting in faster more efficient information processing, leading to increased integration between cortical areas and between subcortical structures.

Higher incidence of myopia, left-handedness, allergies, asthma, and other autoimmune diseases and ear infections: Benbow [62] found a higher incidence of myopia and left-handedness among students exceptionally gifted at mathematics and verbal reasoning than among typical students in Johns Hopkins University's Study of Exceptional Talent. In addition, Benbow [62] found a higher occurrence of allergies, asthma, and other autoimmune diseases in nearly $50 \%$ of the exceptional students in her study. Rogers \& Sil- verman [63] also found a higher occurrence of environmental and food allergies in children with an IQ of 160+, compared to typical children, with a particularly high incidence of milk intolerance and higher frequency of asthma. They found that $44 \%$ of children with an IQ of $160+$ suffered from allergies compared to only $20 \%$ of typical children of the same age and they also reported a significantly high number of ear infections in the former [63].

Prevalence of temporarily low glucose levels: In addition to autoimmune sensitivities, Webb, et al. [7] noted a prevalence of temporarily low glucose levels in highly-profoundly gifted children. Symptoms of foggy head and an inability to concentrate were reported during midmorning and midafternoon. While further study is needed to draw conclusions, Webb [7] believed that this response was reactive hypoglycemia. The phenomenon was relieved by a high-protein snack or meal, and Webb suggested that the greater-than-typical intensity or physical energy of the highly-profoundly gifted literally consumed their "fuel" at a greater-than-typical rate [7].

Increased heart rate in a group of children identified with greater-than-typical sensitivity characteristics: Lagos [64] found an increased heart rate in a group of children identified with greater-than-typical sensitivity characteristics. The children studied felt things deeply, became easily overwhelmed in big crowds, exhibited high sensitivity to stimuli, and felt and perceived the emotions of others. The children were identified as physiologically gifted children (PGC), based on characteristics, behaviors, and development. In this study, a laboratory stress task, the Stroop test, was conducted; the test demonstrated that the PGC's heart rate increased 20 to 60 beats per minute compared to the typical increase of 10 beats per minute.

Studies to date have only begun to uncover the physical and physiological differences associated with advanced, accelerated, or asynchronous development. Further studies of the highly-profoundly gifted are warranted to support their physical health, integrative development, and overall well-being.

\section{Cognitive development}

Terman, Hollingworth and Gross all documented early and accelerated language development in their studies of highly-profoundly gifted children. Terman's [1] study participants acquired language 3.5 months earlier than their sameaged peers, and they were early readers. Hollingworth's [2] case studies indicated that the three most compelling early milestones, demonstrating advanced development, were movement (discussed earlier under physical development), reading, and language acquisition.

Early acquisition of reading and language and rapid learning: Hollingworth [2] also noted that the children in her study spoke considerably earlier than their typical peers, with at least one child speaking as early as at 9 months. Collectively, the children spoke in sentences in their first year of development. Child A, at 16 months, bored of saying the alphabet forward, started saying it backward [2]. Gross [28] noted the moderately gifted speaking at approximately 10 
Citation: Wood VR, Laycraft KC (2020) How Can We Better Understand, Identify, and Support Highly Gifted and Profoundly Gifted Students? A Literature Review of the Psychological Development of Highly-Profoundly Gifted Individuals and Overexcitabilities. Ann Cogn Sci 4(1):143-165

months, while the children in her study of the profoundly gifted spoke at an average of 8.6 months, with several started speaking as early as 6 months. Staines and Mitchell found children typically spoke their first word at 12 months [28]. In addition, Gross [28] noted rapid progression of speech, with the children speaking in sentences an average of 2 months after their first word. This is a remarkable difference; the profoundly gifted children spoke in sentences at 10.6 months on average compared to Jersild's (1960) findings of typically developing children speaking pairs of words at an average of 18 months [28].

Hollingworth [2] noted the strongest early difference between moderately and profoundly gifted children to be in reading ability. All 12 of the children in her study were reading before entering school; the earliest reading age was 2 years, with 10 out of the 12 children reading by the age of 4 years. Gross's findings corresponded with Hollingworth's, with $95 \%$ of the children she studied reading before the age of 5 years. Gross [3] concluded: "The early and superior acquisition of language strengthens crystallized intelligence and permits the child to express sophisticated ideas and questions at a much earlier age than their peers [3]. However, Gross also noted that while early speech is a strong predictor, the absence of speech does not indicate a child is not highly gifted. It is commonly known that Einstein did not speak until he was 3-years-old [28].

Some examples of advanced cognitive development from Gross's studies included Hadley who when asked by her mother how long they had been walking, replied with an exact calculation [3]. Ian, self-taught and propelled by a compulsion to learn everything, thrived on hard work. Typical of the highly-profoundly gifted, lan had to be presented with knowledge at the highest level in order to engage. Similarly, at 10 years of age, Adam self-accelerated; however his teachers were unable to cope with his self-direction. Sally, usually self-reflective, acknowledged the challenge of little supervision as an opportunity for her personal development [3].

The highly-profoundly gifted's ability to learn is significantly more advanced even compared to that of their moderately gifted peers [28]. Hollingworth [2] recognized that a child of 140 IQ can master elementary school work in half the time, and a child of 170 IQ can reach mastery four times faster than his/her peers; Hollingworth called them "rapid learners." Concerned for their optimal development, Hollingworth [2] advocated for their educational and developmental well-being, disclaiming the common myth that "the bright will take care of themselves." These children, like all children, rely on the authority of their elders to guide their well-being and positive development. It is their "Bill of Rights" [65].

Morelock's [66] individual case studies uncovered early developmental milestones in line with those found in studies by Terman, Hollingworth, and Gross. She, too, noted the early, rapid development and acquisition of language skills. In one case study, reading began at 14 months [66]. She identified intellectual stimulation as the "syndrome" of profound giftedness [66], and noted that early reading and language development are strong characteristics of the profoundly gifted. In addition, Morelock [66] cited research that strongly linked the process of language learning to the onset of fundamental changes in the structure and functions of the brain. For instance, according to Rymer [66], language triggers the brain's growth. The field of giftedness would benefit highly from neuroscience research focusing on the profoundly gifted's advanced cognitive abilities and development.

Thriving on complexity: The highly-profoundly create their own complex matrices in order to assimilate and respond to large amounts of concrete information [67]. Their ability to see patterns in abstract material allows complexity to be made relatively simple. Multi-potentiality and divergent thinking capabilities often fuel the likelihood to "overthink." Possibilities are plentiful and easy to consider and formulate [66].

A major component of the learning style of this group is the ability to skip steps in learning, to take giant intuitive leaps. Highly gifted children often surprise adults by arriving at insightful conclusions without being able to describe the steps they took to get there ("I just figured it out").... While their age-mates are comfortable working with concrete material, highly gifted children are more at home with abstractions. They may manipulate abstract symbol systems with ease and become animated when dealing with complex relations involving many variables. They are systems thinkers [22].

The broad acquisition of knowledge of the profoundly gifted appears to be greater than that of their moderately gifted age-mates [66]. The former are extremely rapid learners with an ability to master content instantaneously; they thrive on complexity and seek challenges. They can accelerate radically, and are able to reason abstractly from an early age and decipher meaning or significance, reflecting a sophisticated desire to learn [44]. Complexity and unmatched insights, common traits of the profoundly gifted, are fascinating and perplexing phenomena. The exponential depth and vast breadth of awareness, seemingly innate to this population, make their interconnected thought processes especially challenging to discern. They uniquely prefer engaging in an intricate web of understanding vs. the simple, linear-sequential attainment of knowledge.

In Lovecky's [68] study of 18 profoundly gifted children, she acknowledged their need for complexity. The "simplest" questions were, in fact, the hardest for them to answer. Other indications of advanced cognitive development noted by Lovecky [68] include an exceptional memory and the ability to reason abstractly at a much earlier age than even their moderately gifted peers. Lovecky noted indications of an exceptional memory in the profoundly gifted as early as at 12 months of age.

Intuitive insights: Hollingworth [2], Feldman [16], Morelock [66,69], and Silverman [43] connected the innate, intuitive insights experienced by the extraordinarily gifted to advanced language development. Hollingworth [2] acknowledged that the higher the $I Q$, the greater the need to ponder, contemplate, and make sense of the intricate workings of the universe and the reflective origin and destiny of one's self. 
Citation: Wood VR, Laycraft KC (2020) How Can We Better Understand, Identify, and Support Highly Gifted and Profoundly Gifted Students? A Literature Review of the Psychological Development of Highly-Profoundly Gifted Individuals and Overexcitabilities. Ann Cogn Sci 4(1):143-165

In Gross's study [3], Cassandra displayed heightened sensitivity and awareness expressed through her strong intuition, entelechy, and sense of purpose. Jonathon's heightened awareness and sophisticated ability allowed him to perceive leap years ahead. He studied artificial intelligence and the idea of replacing human reasoning with animal intelligence. Additional research is necessary for a better understanding of the connections between higher-level consciousness and the heightened awareness, abilities and development found in the profoundly gifted population.

\section{Altruistic development}

Profoundly gifted children often display advanced levels of moral development [1]. From an extremely early age, they engage in questions of morality, religion, and philosophical understanding of existence. They embody a strong sensitivity and commitment to truth, justice, and fair play $[2,3,23,43,70,71]$.

Sensitivity and empathy: Sensitivity and empathy, traits commonly associated with altruism, have been reported by Silverman [23] in highly-profoundly gifted children as young as 9 months. The higher the child's IQ, the earlier moral concerns developed and the greater the influence morality had on the child. Silverman [23] also noted that maturity was generally needed before the child could translate moral sensitivity into consistent moral action.

We have dozens of cases on record of gifted children fighting injustice, befriending and protecting handicapped children, conserving resources, responding to others' emotional needs, becoming terribly upset if a classmate is humiliated, becoming vegetarian in meat-eating families, crying at the violence in cartoons, being perplexed at why their classmates push in line, refusing to fight back when attacked because they considered all forms of violence-including self-defense-morally wrong, writing letters to the President to try to end the Gulf War, and writing poems of anguish at the cruelty of the world [23].

Advanced moral reasoning: Many previous researchers have found evidence of advanced moral reasoning in the gifted population [23]. Loye [23] believed moral sensitivity to be an evolutionary process suggesting the greater the moral sensitivity, the greater the intelligence orchestrated by the development of the frontal lobe.

Janos and Robinson [15] used the Defining Issues Test (DIT) to compare the moral reasoning and judgment of highly gifted high school-age students and typical college students and found that the former scored higher than the latter [70]. Howard-Hamilton [72] studied the advanced psychosocial development of five highly gifted girls with IQs of 140-154. They exhibited a complex awareness and understanding of issues such as race and possessed the empathy needed to read group dynamics in a comparison of their sensitivity, awareness, and development with girls more than twice their age. Piechowski [73] suggested that heightened sensitivity, intensity, and awareness demonstrated a high potential for self-actualization. Silverman [43] and Piechowski [73] documented the connection between advanced cognitive abilities and altruistic development. In their studies, they have observed the highly-profoundly gifted's capacity to feel deeply and project the emotions of others, in addition to their own. This powerful interconnection between compassion, empathy, and advanced cognition is the core of giftedness.

Gross [36] recognized the disadvantages of greater moral development at an earlier age. Children from her study were ridiculed and alienated by their peers and teachers. For example, it was noted that Gena was unusually mature, considerate, and endearing to others; however, she was often excluded at school. She displayed heightened sensitivity to and awareness of the devastation shown in world news, and remembered crying when she was not allowed to donate blood [3].

Lovecky [70] described a boy's strong moral development, sensitivity, and willingness to challenge "norms." At age 8 , Nicholas defended children who were not allowed by their peers to join in games. Instead of participating in the behavior he knew to be wrong, he started his own game with the excluded smaller boys and allowed everyone to play.

In general, there have been contradictions in studies examining the correlations between cognitive and moral development. Earlier studies conducted between 1937 and 1959 did not recognize correlations; however, studies conducted between 1962 and 1981 found relationships between cognitive and moral development [74].

\section{Summary}

The most important finding was that intelligence is distinguishable by much more than a single measure of cognitive ability; distinctive social, emotional, physical, altruistic, and cognitive characteristics, behaviors, and development were all reported in relation to unusually high intelligence. Greater-than-typical sensitivity, intensity, and awareness were all common denominators of this population's social, emotional, physical, cognitive, and altruistic development. Holistic studies have demonstrated that unusually high intelligence is not unilateral, but rather multifaceted.

It cannot be sufficiently emphasized that the problems of social isolation, peer rejection, loneliness and alienation which afflict many highly gifted children arise not out of their exceptional intellectual abilities but as a result of society's response to them [3].

How do we respond appropriately and identify holistically our highly-profoundly gifted students? Given the prevalence of misunderstanding, misidentification, and misdiagnosis of the highly-profoundly gifted population [7] and the most recent meta-analysis suggesting potential additional correlations between overexcitabilities and the level of giftedness [6], could the assessment of overexcitabilities be an effective tool for identifying the distinguishing characteristics, behaviors, and development of highly and profoundly gifted students?

\section{Literature Review Results-Part II}

\section{Overexcitabilities and theory of positive disinte- gration}

History of overexcitabilities: The term overexcitabilities 
Citation: Wood VR, Laycraft KC (2020) How Can We Better Understand, Identify, and Support Highly Gifted and Profoundly Gifted Students? A Literature Review of the Psychological Development of Highly-Profoundly Gifted Individuals and Overexcitabilities. Ann Cogn Sci 4(1):143-165

can be traced in the medical literature back to before the $20^{\text {th }}$ century. In 1899 , the Scottish physician Thomas Clouston described "an undue reactiveness to mental and emotional stimuli which in ordinary children would evoke only slight response" [75]. The concept of overexcitability was first introduced into the field of psychology by the Polish psychologist and psychiatrist Kazimierz Dabrowski in 1937. Dabrowski's definition of overexcitabilities exemplified the innate, dynamic characteristics propelling human development. The five forms of overexcitability are the natural propensity to higher developmental pathways. The energy needed to instigate inner growth and the ascending development of the psyche is advanced by the energy exuberated by overexcitability. Dabrowski identified these higher levels in ascending order from 1 to 5, with the self at the dissipating core of each level. In level 1, the self is all powerful and egocentric in nature; the self is the center of its own universe. As one ascends, the self becomes less and less the focus. In level 5, one is said to be self-actualized, life giving, and selfless. It is not typical to reach the peak of level 5; in fact, few do. Only those who have persevered through self-reliance are enlightened by a state of transcendence. This process of transformational growth and development ignited by overexcitabilities was identified by Dabrowski $[76,77]$ as the theory of positive disintegration.

Overexcitabilities as part of the theory of positive disintegration (TPD): Dabrowski's theory of positive disintegration is unique in that it is the only developmental theory that has applied the core characteristics of giftedness [78]. No other theory has included the distinguishing barometers of sensitivity, intensity, awareness, and asynchrony in development, personality, and motivation. Unlike other theories of development dependent on a typical, linear sequential process based on chronological age, Dabrowski's levels of development represent the organic, dynamic, multilevel manifestation of the individual. His theory identified the process of evolving/ climbing between levels. He recognized that development is not linear-sequential, but rather chaotic and disruptive. The challenges encountered and the ensuing difficulties during the climb are the very energy that peaks at advanced development. Dabrowski termed this natural human development process "positive disintegration." The organic breaking down of the psyche, the barriers holding back an individual, must be cleared on the path for greater growth and potential $[77,78]$.

To better understand overexcitabilities as part of this developmental growth process, first, overexcitabilities are defined in context to developmental potential. Next, the characteristics and behaviors are examined within the five forms of overexcitabilities. Followed by, the distinctly different characteristics and behaviors resulting from the combination of multiple, higher-level overexcitabilities and the development of dynamisms. Lastly, the levels of overexcitabilites will be summarized.

Overexcitabilities and developmental potential: One of the essential concepts of the TPD is developmental potential - the original endowment that determines the level of development a person may reach if the physical and environmental conditions are optimal for the individual. In other words, the developmental potential of an individual is reached by bringing order to the chaos of the conflicts generated by the multiple components of the original endowment [77]. Developmental potential contains three sets of factors that control development: The first factor represents innate constitutional and biological potentialities of the organism; the second factor represents all social and environmental influences; and the third factor represents those autonomous processes, such as internal conflicts, self-awareness, choices, and decisions in relation to personal growth, and conscious inner psychic transformation, that the person brings into his or her development [79]. The developmental potential may be particularly strong when, in addition to these factors, there are special abilities and talents and particular strengths of self-awareness and self-determination [77].

Based on his observation of creative and gifted individuals, Dabrowski introduced overexcitability as additional factors of developmental potential. He defined this phenomenon as a higher than average responsiveness of the nervous system $[5,76]$. The prefix over, attached to excitability, serves to indicate that the reactions of excitation are over and above average in intensity, duration, and frequency [77]. Overexcitability in gifted and creative people explains the intensity of their daily life experiences.

Five forms - characteristics and behaviors of overexcitabilities: Dabrowski introduced the five forms of overexcitability-psychomotor, sensual, imaginational, intellectual, and emotional. Psychomotor overexcitability is the manifestation of heightened energy levels seen in rapid talk, restlessness, the pressure for action, etc. Sensual overexcitability is characterized by heightened responses of the senses manifesting as extreme pleasure or displeasure, magnification of tactile senses such as the irritation of a shirt tag, or a sense of away or appreciation for natural or simplistic beauty and aesthetics. Imaginational overexcitability manifests through invention as well as unique or expressive images, metaphors, fantasies, and animistic thinking. Intellectual overexcitability is most frequently associated with intensified theoretical thinking manifested as a drive to ask probing questions, avidity for knowledge, theoretical thinking, and preoccupation with theoretical problems. Emotional overexcitability is a function of emotional relationships, manifested as strong attachments to people, living things, or places. The expressions of emotional overexcitability include timidity and shyness, enthusiasm, strong affective memory, concern with the death of others, exclusive relationships, and difficulties of adjustment to new environments $[21,77,80,81]$.

The strength of overexcitabilities can be viewed "as a channel through which information flow in the form of sensations, feelings, experiences, images, ideas, hopes, and desires. These channels can be wide open, narrow, or operating at bare minimum. They are assumed to be part of a person's constitution and to be more or less independent of each other. If more than one of these channels have wide apertures, then the abundance and diversity of feeling, thought, imagery, and sensation will inevitably lead to dissonance, conflict, and tension" [81]. Examples of psychomotor, sensual, intellectual, imaginational, and emotional overexcitabilities identified by Daniels and Piechowski [82] and Lind [83] are shown in Table 3. 
Citation: Wood VR, Laycraft KC (2020) How Can We Better Understand, Identify, and Support Highly Gifted and Profoundly Gifted Students? A Literature Review of the Psychological Development of Highly-Profoundly Gifted Individuals and Overexcitabilities. Ann Cogn Sci 4(1):143-165

Table 3: The five forms of overexcitabilities (OE; based on Dabrowski \& Piechowski, Piechowski, Daniels \& Piechowski, Lind) [21,80,81,83].

\begin{tabular}{|c|c|c|c|c|}
\hline Sensual OE & Psychomotor OE & Imaginational OE & Intellectual OE & Emotional OE \\
\hline $\begin{array}{l}\text { Heightened experience of } \\
\text { sensual pleasure or displeasure } \\
\text { including all senses }\end{array}$ & $\begin{array}{l}\text { Heightened excitability } \\
\text { of the neuromuscular } \\
\text { systems. Intense } \\
\text { physical activity and a } \\
\text { need for action }\end{array}$ & $\begin{array}{l}\text { Heightened play of } \\
\text { the imagination, } \\
\text { visualization, and } \\
\text { association }\end{array}$ & $\begin{array}{l}\text { To seek understanding } \\
\text { and truth }\end{array}$ & Heightened, intense feelings \\
\hline Experience in extreme & High energy level & $\begin{array}{l}\text { Imagine many } \\
\text { possibilities }\end{array}$ & $\begin{array}{l}\text { Passion for learning and } \\
\text { making sense of things }\end{array}$ & $\begin{array}{l}\text { Emotions deeply processed } \\
\text { and displayed very strongly }\end{array}$ \\
\hline $\begin{array}{l}\text { - Experience of a magnificent } \\
\text { sunset, music or artwork } \\
\text { may move the whole being } \\
\text { - May seek sensual experience } \\
\text { or may feel overstimulated/ } \\
\text { uncomfortable with } \\
\text { abundance of sensory input } \\
\text { and withdrawal completely } \\
\text { - Experience may include } \\
\text { irritating clothing tag, } \\
\text { classroom noise, or } \\
\text { environment smell }\end{array}$ & $\begin{array}{l}\text { - } \text { Show intense drive } \\
\text { - } \text { ind great joy from } \\
\text { - } \text { Rapid speech or } \\
\text { "surplus of energy" } \\
\text { - Talk compulsively } \\
\text { - Act impulsively } \\
\text { - Misbehave } \\
\text { - Display nervous } \\
\text { - habits } \\
\text { - Tapping feet, biting } \\
\text { - } \text { nails } \\
\text { Potential for being } \\
\text { misdiagnosed with } \\
\text { Attention Deficit } \\
\text { Hyperactivity } \\
\text { Disorder (ADHD; } \\
\text { Lind, 2001) }\end{array}$ & $\begin{array}{l}\text { - } \text { Visual thinkers } \\
\text { - } \text { Abstract minds } \\
\text { - } \text { Out-of-box } \\
\text { thinkers } \\
\text { - Can create and } \\
\text { live in their own } \\
\text { worlds- in their } \\
\text { heads } \\
\text { - May be a coping } \\
\text { mechanism for } \\
\text { companionship } \\
\text { or boredom }\end{array}$ & $\begin{array}{l}\text { - High in metacognition, } \\
\text { thinking about } \\
\text { thinking } \\
\text { - Strong concerns for } \\
\text { moral issues, fairness, } \\
\text { and world problems } \\
\text { - Love of theory } \\
\text { - Big picture thinkers } \\
\text { - Strategic mind-set } \\
\text { - Exceptional processing } \\
\text { - } \text { abilities } \\
\text { - } \text { Keenly observant } \\
\text { - } \text { solvacious problem } \\
\text { - Avid readers } \\
\text { - } \text { Appear critical, } \\
\text { impatient } \\
\text { Frustrated when } \\
\text { others cannot follow } \\
\text { their pace }\end{array}$ & $\begin{array}{l}\text { - Extraordinary awareness } \\
\text { - Extreme compassion, } \\
\text { - } \text { Practice self reflection } \\
\text { - Strong connection to } \\
\text { self, feelings, inner } \\
\text { development } \\
\text { - Ability to deeply } \\
\text { connect with people and } \\
\text { environment } \\
\text { - Physical manifestation } \\
\text { may include stomach } \\
\text { aches, flushed skin, and } \\
\text { depression }\end{array}$ \\
\hline
\end{tabular}

Lind [83] recognized high occurrence of overexcitabilities in the highly gifted yet also stated that not all highly gifted children exhibit overexcitabilities. It is important to recognize overexcitabilities are typical of the highly-profoundly gifted population, although not without exceptions. This literature review summarizes the characteristics, behaviors, and development typical of highly-profoundly gifted children and the characteristics, behaviors and development of overexcitabilities to recognize correlations and to provide a platform, a starting point, for further research and better identification.

Characteristics and behaviors of the combination of multiple, higher-order over-excitabilities: Children exhibiting multiple overexcitabilities combined with special abilities display characteristics, behaviors, and development that are different from those of their age-peers. The distinguishing differences appear to lie in the energy-the heightened sensitivity, intensity, awareness, and asynchrony of the individual-rather than in the characteristic itself. Piechowski $[84,85]$ provided an in depth view of the distinguishing characteristics, behaviors, and development of children exhibiting multiple overexcitabilities (Reference Antoine de Saint-Exupéry, Piechowski and Peace Pilgrim, Piechowski) [85]. Both case studies provided a glimpse of the heightened sensitivity, intensity and awareness exhibited in the characteristics, behaviors and development of a child with multiple over-excitabilities. The five forms of overexcitability undergo extensive differentiation as human beings develop. Intellectual, imaginational, and emo- tional overexcitablities combine to play a significant role in the formation of developmental dynamisms that shape and direct personality development [77].

The levels of development - from overexcitabilities to dynamisms: One of the most significant innovations of the theory of positive disintegration is the concept of dynamisms. Dynamisms form from the combination of multiple, higher-level overexcitabilities. Dynamisms reorganize human growth through instinctual, emotional, and cognitive forces. They can interact either synergistically or antagonistically depending on the level of integration and the developmental potential of the individual $[77,79,86]$.

According to Dąbrowski $[76,77]$ positive disintegration is multilevel development where each level represents a qualitatively distinct, relatively stable, and developmentally coherent structure, characterized by distinctive sets of developmental dynamisms that interact with each other, creating unique patterns of behavior. The process of positive disintegration includes five clearly distinguishable levels: (1) Primary integration; (2) Unilevel disintegration; (3) Spontaneous multilevel disintegration; (4) Organized multilevel disintegration; and (5) Secondary integration [76,77,79].

The first level: Primary integration: The first level of development-primary integration-defines a narrow, rigid, automatic structure governed by the first factor. No overexcitability or only the psychomotor or sensual forms are observed at 
Citation: Wood VR, Laycraft KC (2020) How Can We Better Understand, Identify, and Support Highly Gifted and Profoundly Gifted Students? A Literature Review of the Psychological Development of Highly-Profoundly Gifted Individuals and Overexcitabilities. Ann Cogn Sci 4(1):143-165

this level. Therefore, no developmental dynamisms are associated with this mental structure. Individuals on this level are not capable of having internal conflicts, although they often have conflicts with their external environment. They cannot follow long-range plans, and are limited to the reality of their immediate, passing feelings. Strong external stimuli and stressors may only temporarily bring psychic changes, but they are inevitably short and ineffective. They quickly return to the patterns of primary integration [87].

The second level: Unilevel disintegration: Unilevel disintegration begins with the loosening of the undifferentiated structure of primary integration. Changeable feelings, such as like and dislike, approach and avoidance, conflicting courses of action, indecision and doubt, replace the rigid behaviors of primary integration. Patterns of thought are often circular. Internal conflicts appear but are unilevel. External conflicts persist from primary integration but are not particularly aggressive and can be unpredictable. Behavior in this mode conforms to external standards (what people will think or say).

The third level: Spontaneous multilevel disintegration: As development continues, a third factor (the autonomous and intrapsychic processes) starts to operate, and unilevel disintegration shifts to multilevel hierarchical organization-spontaneous multilevel disintegration. It is characterized by extensive differentiation of mental structures. Individuals notice higher and lower levels of experience and search for models in their environment. This level is indicated by the increasing role of inner conflict and a gradual decrease in the frequency of external conflict. Internal conflicts reflect a hierarchical structure of cognitive and emotional life- "what is" versus "what ought to be." A previously unilevel attitude of like and dislike is transformed into an understanding of others and a growing desire to have deeper and more selective relationships. This state is dramatic and marked by a sharp turning toward oneself in order to seek solutions within. The transition from unilevel disintegration to multilevel disintegration is a crucial and unexpected developmental event $[5,77]$. Through developmental dynamisms, abrupt changes in human behavior are observed.

The first phase of the third level is characterized by emotional-cognitive dynamisms [77]: Astonishment with oneself, the first phase in the authentic observation of oneself and the beginning of the desire to change; disquietude with oneself, the search for the meaning of one's behavior and existence and a growing attitude of self-criticism, with emotional tension and readiness toward inner psychic transformation; dissatisfaction with oneself, a critical, condemning attitude toward oneself accompanied by states of anxiety and depression; and feelings of inferiority toward oneself, the awareness of the possibility of development, the awareness of weakness, and, at the same time, the feeling of one's potential and strength. These dynamisms create states of self-observation, self-reflection, self-awakening, self-criticism, and self-awareness. They are the product of emotional and intellectual overexcitabilities. Intellectual overexcitability enhances the development of self-awareness [77].

The second phase of the third level involves continued emotional-cognitive development creating a new class of dynamisms that includes embarrassment, shame, and guilt-the self-conscious emotions. These emotions require the ability to evaluate one's self and to infer the mental states of others $[77,88]$. Self-conscious emotions are important for helping individuals recognize and correct their social mistakes, strengthen social bonds, renew commitment to relationships, and motivate positive behavior [89]. They provide internal feedback about a specific goal, expectation, or standard that has been violated. Violation of social conventions may result in embarrassment, whereas violations of character ideas are associated with shame, and violations of rules, related to harm, justice, and rights, can cause guilt [90]. These self-conscious dynamisms are the result mostly of emotional and intellectual overexcitability, with some involvement of imaginational overexcitability.

The third phase of the third level involves spontaneous multilevel disintegration and emergence of positive maladjustment. This is the dynamism of a conscious and selective rejection, or a need for adaptation to a higher hierarchy of value, and is characterized by a lack of adjustment to certain external or internal conditions. It expresses the drive toward accelerated development, self-perfection, and the realization of an attitude of autonomy and authenticity. The dynamism of positive maladjustment is connected to the understanding of others and their needs [86]. It is a product of emotional, cognitive, and imaginational overexcitabilities.

By observing and studying gifted and creative people, Dabrowski [86] proposed that creative dynamisms emerge during the process of spontaneous multilevel disintegration. Creative dynamisms arise from above-average sensitivity, and develop under conditions of emotional turmoil, mental tension, and internal conflict. They help to break the barrier of routine and liberate oneself from automatic experiences in order to achieve inner autonomy. They are an expression of a "psychological awakening", an important outlet for the increased tension of inner conflict and a vital force of defense against mental illness. As a result of creative dynamisms, individuals can experience the states of elation, pleasure, pride, and joy $[79,86]$. Creative dynamisms emerge as a combination of emotional, intellectual, and imaginational overexcitabilities; in some cases, sensual or psychomotor overexcitability is also involved.

In her study of creative young people, Laycraft [32] showed that some participants were endowed with four forms of overexcitability. For example, one of her participants, Krista, a contortionist, was equipped with intellectual overexcitability (creating a concept for the piece of contortion), emotional overexcitability (expressing emotions during her performance), imaginational overexcitability (drawing inspiration from some visual forms), and psychomotor overexcitability (performing actual contortion movements; p. 137).

Positive maladjustment and creative dynamisms help to reorganize a disintegrated mental structure and build a new reality through expanded awareness. It is a starting point for the transition to the next level.

The fourth level: Organized multilevel disintegration: 
As development continues, individuals take the initiative in organizing hierarchies in their inner worlds. This is a period of organized multilevel disintegration directed and controlled by highly conscious, autonomous, and self-determining processes that stabilize and organize mental structures. The characteristic feature of this level is the conscious transformation that leads to increasing stabilization of the hierarchy of values. There are still some existential and philosophical conflicts, but with less tension. Conflicts, depression, and states of anxiety are handled consciously, and transformed into processes of enrichment and strengthening of one's development. This level is characterized by openness, sensitivity, and identification with others. Behavioral changes toward self-perfection and emotional relationships become deeper and more enduring $[5,77,79]$.

The dynamisms of organized multilevel disintegration now work closely together and stabilize the following mental structures: "Subject-object" in oneself, the critical observation, self-evaluation, and conscious need for development, working closely with the dynamism of inner psychic transformation; inner psychic transformation, the process of developmental change in personality structure, especially the emotional; the third factor, the autonomous forces of self-directed development and conscious choices of development; self-awareness, the awareness of one's identity and one's individual uniqueness; self-control, bringing order and unity into one's development, increasing calmness and confidence; creative dynamism participating in the organization of new, more complex structure; and empathy emerging when the "subject-object" in oneself, self-awareness, and the third factor intertwine and interact with one another $[77,80]$. All or at least four of the five forms of overexcitabilities (emotional, intellectual, imaginational, sensual, or psychomotor) are involved in the formation of these dynamisms. At this level, individuals integrate opposing attributes into higher-order abstractions that bring meaning and authenticity to what in earlier times appeared to be upsetting contradictions within the self [91].

The fifth level: Secondary integration: As developmental potential becomes more complex, and includes all forms of overexcitability and special abilities and talents, the highest level of development can be reached. This is the fifth level of secondary integration, characterized by a new organization and harmonization of personality. Personality becomes a self-aware, self-chosen, and self-affirmed structure. It is then a synthesis of the most essential human values embodied in the individual. The main dynamisms active at this level are responsibility for oneself and others, the source of responsibility being the highest level of empathy and love for every human being and the need to turn this love into action; au-

\section{Dynamisms}

- Responsibility for oneself \& others

- Autonomy

- Authenticity

- Profound \& active empathy

- Personality ideal

- Subject-object in oneself

- Inner psychic transformation

- The Third factor

- Self-awareness

- Self-control

- Creative dynamism II

- Empathy

- Astonishment with oneself

- Disquietude with oneself

- Dissatisfaction with oneself

- Feeling of inferiority

- Guilt, shame \& embarrassment

- Positive maladjustment

- Creative dynamism I

- Ambivalence

- Ambitendency

No dynamisms

\begin{tabular}{l|l} 
Secondary & D \\
integration & e \\
& v \\
& I \\
& o \\
& p \\
Organized & r \\
multilevel & e \\
disintegration & n \\
& t \\
& a \\
Spontaneous & I \\
multilevel & p \\
disintegration & t \\
& e \\
& $\mathbf{n}$ \\
Unilevel & i \\
disintegration & a \\
& I \\
Primary & \\
integration &
\end{tabular}

Three factors Five forms of overexcitabilities Talents

\section{Three factors \\ Four forms of overexcitabilities}

\author{
First, second, third factors \\ Emotional, intellectual and \\ imaginational overexcitabilities
}

\section{First and second factors Conflicting excitations}

\author{
First factor \\ No overexcitabilities or only \\ psychomotor or sensual \\ overexcitabilities
}

Figure 1: The levels of overexcitabilities (OEs) and dynamisms. 
Citation: Wood VR, Laycraft KC (2020) How Can We Better Understand, Identify, and Support Highly Gifted and Profoundly Gifted Students? A Literature Review of the Psychological Development of Highly-Profoundly Gifted Individuals and Overexcitabilities. Ann Cogn Sci 4(1):143-165

tonomy, signifying the realization of the meaning and value of human experience; authenticity, being the freedom from lower level drives, behaviour, and the influence of the external environment; and personality ideal, playing an increasingly significant role in the synthesis of the inner psychic milieu. There are no internal conflicts; rather, there is a profound and active empathy expressed as spontaneous readiness for sacrifice, protection of others, deep understanding of others' development, and compassion over the difficulties of the world [77,79] (Figure 1).

Levels of overexcitabilities: At lower levels of development, overexcitabilities occur in isolation from one another. As we discussed above, the first level, primary integration, is characterized by a lack of any overexcitability, or only by a single overexcitability (psychomotor or sensual). However, at higher levels of development, overexcitabilities, by inter- acting and combining with each other, introduce significant changes in the quality of each form of overexcitability, and consequently produce coherent and higher-order arrangements called developmental dynamisms, and through them, substantial changes in human behavior [77].

As we have shown above, dynamisms of the third level of development are the product of emotional overexcitability, while simultaneously intellectual overexcitability enhances the development of self-awareness. These dynamisms create states of self-observation, self-reflection, self-awakening, self-criticism, and self-awareness. Their main role is to shatter the pre-existing organization of the lower levels of development.

A combination of emotional, intellectual, and imaginational overexcitabilities gives rise to higher levels of dyna-

Table 4: The levels of overexcitabilities (OEs; Dabrowski, 1996 [77]).

\begin{tabular}{|c|c|c|c|c|c|}
\hline Level & Sensual OE & Psychomotor OE & Imaginational $\mathrm{OE}$ & Intellectual OE & Emotional OE \\
\hline IV & $\begin{array}{l}\text { Never appears in } \\
\text { isolation from other } \\
\text { forms of OE } \\
\text { - Esthetic sensitivity to } \\
\text { the beauty of nature } \\
\text { and art } \\
\text { - Adds warmth and } \\
\text { cordiality in expressing } \\
\text { empathy }\end{array}$ & $\begin{array}{l}\text { - By cooperating with } \\
\text { other OE gives them } \\
\text { "executive power" } \\
\text { - Provides dynamics } \\
\text { and energy for } \\
\text { decisions and actions } \\
\text { - Increased } \\
\text { responsibility and } \\
\text { punctuality }\end{array}$ & $\begin{array}{l}\text { By Linking with other } \\
\text { forms of OE plays } \\
\text { a role in conscious } \\
\text { development of } \\
\text { personality } \\
\text { - Engagement in } \\
\text { the realization of } \\
\text { transcendental } \\
\text { needs } \\
\text { - Merges with the } \\
\text { need for mystical } \\
\text { experiences }\end{array}$ & $\begin{array}{l}\text { By a close linkage } \\
\text { with other forms } \\
\text { of OE gives rise to } \\
\text { creative intelligence } \\
\text { - Extensive, universal } \\
\text { \& multilevel } \\
\text { intellectual interest } \\
\text { - Inclinations toward } \\
\text { synthesis } \\
\text { - The desire to } \\
\text { be objective in } \\
\text { understanding of } \\
\text { the hierarchy of } \\
\text { values }\end{array}$ & $\begin{array}{l}\text { - In association } \\
\text { with other forms } \\
\text { of OE gives } \\
\text { rise to higher } \\
\text { consciousness } \\
\text { Gives rise to } \\
\text { - Profound \& deep } \\
\text { empathy } \\
\text { - Depth and } \\
\text { exclusivity of } \\
\text { relationships } \\
\text { of love and } \\
\text { friendship } \\
\text { - Elevated } \\
\text { consciousness }\end{array}$ \\
\hline III & $\begin{array}{l}\text { Strong linkage with } \\
\text { emotional and } \\
\text { imaginational OE } \\
\text { - Establishes a hierarchy } \\
\text { of sensual experience }\end{array}$ & $\begin{array}{l}\text { - Close linkage } \\
\text { with emotional, } \\
\text { imaginational \& } \\
\text { intellectual OE } \\
\text { - Search for channels } \\
\text { "upward" } \\
\text { - Formation of } \\
\text { decisiveness }\end{array}$ & $\begin{array}{l}\text { Close linkage with } \\
\text { emotional, and } \\
\text { intellectual OE } \\
\text { - Differentiation of } \\
\text { imagination and } \\
\text { creativity } \\
\text { - A growing sense of } \\
\text { humor }\end{array}$ & $\begin{array}{l}\text { - Intensifies the } \\
\text { activity of all } \\
\text { dynamisms } \\
\text { - Enhances awareness } \\
\text { - Need for finding } \\
\text { the meaning of } \\
\text { knowledge and } \\
\text { human experience } \\
\text { - Intuitive intelligence }\end{array}$ & $\begin{array}{l}\text { - A union with } \\
\text { intellectual and } \\
\text { imaginational } \\
\text { OE produces } \\
\text { dynamisms } \\
\text { - Growth of } \\
\text { friendship and } \\
\text { love } \\
\text { - Increases } \\
\text { empathy \& self- } \\
\text { awareness; }\end{array}$ \\
\hline ॥ & $\begin{array}{l}\text { - Short-lived } \\
\text { astonishment or } \\
\text { disquietude to } \\
\text { sensuality }\end{array}$ & $\begin{array}{l}\text { - Ambivalence and } \\
\text { ambitendencies } \\
\text { - Intensifies reflexes } \\
\text { (trembling of hands } \\
\text { and feet, ticks) } \\
\text { - Awkwardness of } \\
\text { movement }\end{array}$ & $\begin{array}{l}\text { - Primitive } \\
\text { suggestibility (magic, } \\
\text { witchcraft) } \\
\text { - Taste for fantasy and } \\
\text { adventure stories } \\
\text { - Frequent dreams } \\
\text { and daydreaming }\end{array}$ & $\begin{array}{l}\text { - Lack of need to get } \\
\text { into the meaning of } \\
\text { knowledge } \\
\text { - One-sided abilities }\end{array}$ & $\begin{array}{l}\text { - } \text { Approach \& } \\
\text { avoidance } \\
\text { - High tension and } \\
\text { depression } \\
\text { - Weak forms of } \\
\text { affective memory }\end{array}$ \\
\hline I & $\begin{array}{l}\text { - Excessing kissing, } \\
\text { - Excessing eating, } \\
\text { nibbling } \\
\text { - Laziness }\end{array}$ & $\begin{array}{l}\text { - Violent irritability } \\
\text { and uncontrolled } \\
\text { temper, } \\
\text { - Impulse actions } \\
\text { - Juvenile delinquency }\end{array}$ & $\begin{array}{l}\text { - Lack of perspective } \\
\text { and retrospective } \\
\text { thinking } \\
\text { - Tendency to } \\
\text { confabulate, lies, and } \\
\text { acting }\end{array}$ & $\begin{array}{l}\text { - Skillfull } \\
\text { manipulation } \\
\text { of data and } \\
\text { information } \\
\text { - Intelligence rather } \\
\text { than intellectual OE }\end{array}$ & $\begin{array}{l}\text { - Aggressiveness, } \\
\text { irritability, } \\
\text { - Lack of control, } \\
\text { - Envy, } \\
\text { - Need for } \\
\text { attention }\end{array}$ \\
\hline
\end{tabular}


Citation: Wood VR, Laycraft KC (2020) How Can We Better Understand, Identify, and Support Highly Gifted and Profoundly Gifted Students? A Literature Review of the Psychological Development of Highly-Profoundly Gifted Individuals and Overexcitabilities. Ann Cogn Sci 4(1):143-165

misms, such as positive maladjustment and creative dynamisms. They are observed in the transition from the third to the fourth level of development. In these dynamisms, imaginational overexcitability enriches them through strong visualization, fantasy, and the foreseeing of the future. Their main role is to help reorganize a disintegrated mental structure and build a new reality through expanded awareness.

Next, the interconnection of four forms of overexcitability, observed in the fourth level of development, produces greater psychic complexity, higher levels of creativity, heightened self-awareness, and improved social responsibility. At this level, psychomotor overexcitability is manifested as an increasing ability for initiating dynamic courses of action, responsibility and punctuality, and organizational abilities. Finally, at the fifth level, secondary integration, the five forms of overexcitability are bonded together into a harmonious and flexible whole, called the personality ideal [77] (Table 4).

Overexcitabilities assessment measures - OEQ and OEQ II: Dabrowski's studies and conception of overexcitabilities were multi-disciplinary, and incorporated work in medicine, psychoanalysis, neurology, and internal disease [92]. In his pediatric work, Dabrowski and his students, conducted neurological examinations to assess overexcitabilities and developmental potential in children. Piechowski worked with Dabrowski to develop research on overexcitabilities and gifted adolescents. In 1975, Piechowski developed the overexcitabilities questionnaire (OEQ) as the first identification tool for the measurement of overexcitabilities. The Overexcitability Questionnaire (OEQ), consisted of 21 open-ended questions [93]. To improve upon the OEQ, Falk, Lind, Miller, Piechowski, and Silverman [94] designed the OEQ II. It used a five-point Likert scale and consisted of 50 questions: 10 questions to assess each of the five forms of overexcitabilities. The OEQ II has been shown to be statistically reliable with positive factor analysis and an internal validation of 0.84-0.89.

Psychologists, including Piechowski, Daniels, Silverman, Lovecky, Meckstroth, and Webb, found overexcitabilities best described the qualities and dynamic characteristics, behaviors, and development of gifted children, adolescents, and adults. "Generally, the brighter, the more inquisitive, and the more creative the child, the more likely it is that the child's overexcitabilities and related behaviors and needs will permeate and influence daily behaviors" (Daniels, p.20) [95]. Jackson, a therapeutic counselor working with highly-profoundly gifted children, described overexcitabilities as a "qualitatively different" experience, "not just more of curiosity, sensory enjoyment, imagination and feeling but added dimensions of depth, texture, acuity, and perception. It implies an intense aliveness and a neural processing very different from the norm" [96].

Studies of overexcitabilities, giftedness, gifted identification: Overexcitabilities have been studied in various contexts, which include variables such as age, gender, culture, creativity, artistic talent, brain structure and giftedness [21,97-100]. Research has shown gifted individuals tend to have more overexcitabilites than their typical peers [16,98,101-105]. Additionally, research has found overexcitabilities to be an effective tool for gifted identification $[98,106,107]$.
Two recent meta-analyses $[6,108]$ agree with this observation; both analyses found the mean scores of all five overexcitabilities to be statistically significantly higher in gifted individuals than in their non-gifted peers. Intellectual overexcitability was the highest discriminant factor between gifted and non-gifted individuals followed by imaginational overexcitability $[6,108]$, whereas psychomotor overexcitability was the least discriminant [6].

Steenbergen-Hu [6] took the analysis a step further by re-examining the gifted participants' scores by the level of overexcitability giftedness (low, medium, or high). She found the "highly gifted" scored significantly higher than their typical peers on intellectual, imaginational, and sensual overexcitabilities in six of the eight studies in the meta-analysis. This significant correlation seemed to imply that overexcitabilities were more dominant in "high" gifted individuals [6]. Of additional significance, Steenbergen-Hu examined the difference in mean effect size when giftedness was identified using multiple measurements versus a single non-verbal score. In all the studies that identified giftedness using multiple measurements, she found the gifted participants significantly outscored the non-gifted participants on all measures of overexcitability [6].

These two findings imply that assessment of overexcitabilities may be effective for identifying highly-profoundly gifted students. Moreover, these results validate the need for multiple measures of assessment or a holistic examination of the child to accurately uncover and identify the multifaceted development and potential of the highly-profoundly gifted individual.

Piechowski [21], Ackerman [98], Tucker \& Hafenstein [106], and Bouchard [107] believed the assessment of psychic overexcitabilities, observed in the characteristics, behaviors, and development of students, to be a valid tool for identifying gifted individuals. Steenbergen-Hu's [6] recent meta-analysis validates the positive correlation between overexcitabilities and giftedness, and provides additional analysis indicative of increasing level of giftedness with increasing overexcitability score.

Additionally, examination of overexcitabilities and brain structure has provided intriguing correlations for further investigation. For example, Kuo, et al. [109] looked at the gray matter volume in relation to overexcitabilities and found the following relationships: Sensual overexcitability was positively correlated to the gray matter volume of the left superior temporal gyrus; intellectual overexcitability was positively correlated to the gray matter volume of the left inferior parietal lobule (BA 40), left superior temporal gyrus (BA 22), left parietal supramarginal gyrus (BA 40), and right inferior parietal lobule (BA 40); imaginational overexcitability was positively correlated to the right inferior parietal lobule (BA 40) and right parietal supramarginal gyrus; and emotional overexcitability was negatively correlated to the gray matter volume of the left superior temporal gyrus (BA 22). Future studies using magnetic resonance imaging (MRI) for effective physiological identification of overexcitabilities and/or giftedness are recommended. 
Citation: Wood VR, Laycraft KC (2020) How Can We Better Understand, Identify, and Support Highly Gifted and Profoundly Gifted Students? A Literature Review of the Psychological Development of Highly-Profoundly Gifted Individuals and Overexcitabilities. Ann Cogn Sci 4(1):143-165

Example of misunderstanding of giftedness and overexcitabilities in recent study: Identified as the problem in the introduction, and acknowledged throughout this review, giftedness has often been misunderstood, misidentified, and misdiagnosed by untrained professionals [7]. Therefore, discrepancies in a recent study of giftedness and overexcitabilities must be addressed based on the research in this literature review. Karpinski, Kinase Kolb, Tetreault, and Borowski [110] suggested a potential relationship between intelligence, overexcitabilities, and psychological disorders. However, the study did not introduce or examine overexcitabilities in context to Dabrowski, the creator of overexcitabilities, or the theory of positive disintegration.

Additionally, the study only considered attention deficit hyperactivity disorder (ADHD) as a possible misdiagnosis of giftedness. The study considered Autism Spectrum Disorder, Bipolar and other mood disorders as psychological disorders, but overlooked the prevalence of misunderstanding, misidentification, and misdiagnosis of the gifted or highly-profoundly gifted population as acknowledged by Webb, et al. [7].

\section{Discussion}

Correlations between the distinctive social, emotional, physical, cognitive, and altruistic characteristics, behaviors and development of the highly-profoundly gifted and overexcitabilities

Given the prevalence of misunderstanding, misidentification, and misdiagnosis of the highly-profoundly gifted population [7] and the most recent meta-analysis suggesting additional potential correlations between overexcitabilities and the level of giftedness [6], could the assessment of overexcitabilities be an effective tool for identifying the distinguishing characteristics, behaviors, and development of highly and profoundly gifted students?

Studies on characteristics, behaviors, and development of the highly-profoundly gifted population and overexcitabilities acknowledged corresponding influences and significant similarities between all areas of development and developmental potential. To answer the literature review question above, correlations are identified for the factors linked to developmental potential in Dabrowski's theory of positive disintegration and the corresponding biological-physical, social-environmental, emotional, cognitive, and altruistic characteristics, behaviors, and development.

Biological and physical characteristics, behaviors, and development: Dabrowski [5] observed and documented high developmental potential exhibited by greater-than-typical action-oriented movement and verbal activity he called psychomotor overexcitability. Similarly, Terman [1], Hollingworth [2], and Gross [3] reported advanced development demonstrated by early onset of movement and language acquisition [1-3]. Moreover, it was found, psychomotor overexcitability ignites the combination of intellectual, imaginational and/ or emotional overexcitabilities - active traits of highly-profoundly gifted children and high developmental potential $[21,80,87]$.
In terms of physiology, greater-than-typical sensitivity, including the prevalence of autoimmune, allergy, and asthmatic reactions and increased heart rate corresponded with the greater-than-typical sensitivity characteristic of overexcitability of the neuromuscular system (refer back to Table 3).

Social and environmental characteristics, behaviors, and development: In an unfit environment, gifted children with high developmental potential display symptoms of inefficient psychic excitability, often displayed as nervousness, and anxiety; consequently, their development is inhibited. Similarly, in longitudinal studies of highly-profoundly gifted children, Terman, Hollingworth, and Gross [1-3] documented the historical impact of the social and environmental roles played by various stakeholders. The development potential of an individual is supported when the social and physical environment is optimal [77]. Only a safe, trusting, and open-hearted environment is able to activate and boost the development of young people to a healthier, richer, and higher level, where there is much less tension and mental disorder [32].

Emotional characteristics, behaviors, and development: The emotional development of the highly-profoundly gifted is the driving factor of giftedness [41,45-47]. Likewise, emotional overex-citability is the driving factor of developmental potential $[21,76,80,81,111,112]$.

A closer look at heightened sensitivity revealed the likelihood of discernment, response, feeling and display of emotions, aesthetics, and sensitivity to others as characteristic traits of the highly-profoundly gifted [44]. Similarly, the same traits can be related to corresponding overexcitabilities and/ or dynamisms: Feeling and display of emotions to emotional overexcitability [82]; aesthetics to Level IV of emotional overexcitability combined with sensual overexcitability; discernment to Level III of emotional overexcitability combined with intellectual overexcitability; and sensitivity to others to Levels III and IV of the dynamism characteristic empathy.

Case studies of highly-profoundly gifted children have demonstrated their understanding of perceptions and nuances not apprehended by others [3]. This greater-than-typical awareness is evident in all five overexcitabilities: The need for action in psychomotor overexcitability [51]; pleasure or displeasure in sensual overexcitability $[21,51,80]$; understanding and truth in intellectual overexcitability $[21,51,80]$; the abstract and association in imaginational overexcitability [82]; and feelings of self and for others in emotional overexcitability [82].

Highly gifted children tend to have more intense, stronger, and more memorable reactions [32]. Likewise, greater-than-typical intensity and reactions to stimuli are the very nature of overexcitabilities [82]. Moreover, the acute awareness exhibited by the highly-profoundly gifted has been observed as early as birth $[3,12,39]$. Acute awareness has been described as innate to overexcitability [82], and includes feelings of being different throughout the life span. Acute and profound awareness is correlated with feelings of inferiority toward oneself (Level III dynamism) and self-awareness and self-control (Level IV dynamism). In addition, highly-profoundly gifted children tend to possess a natural tendency 
Citation: Wood VR, Laycraft KC (2020) How Can We Better Understand, Identify, and Support Highly Gifted and Profoundly Gifted Students? A Literature Review of the Psychological Development of Highly-Profoundly Gifted Individuals and Overexcitabilities. Ann Cogn Sci 4(1):143-165

to being introspective-emotional, just as the dynamisms associated with overexcitabilities and development encourage introspection, emotional reflection, and deep-seated connection within themselves and their environment [51].

Highly-profoundly gifted children often describe a strong sense of right and wrong and an internal guide from within; this is the third-factor dynamism present in the combination of multiple overexcitabilities and multifaceted development and potential [79]. A strong sense of right and wrong is associated with positive maladjustment (Level III dynamism). An internal guide from within is correlated to the third factor (Level IV dynamism). Multifaceted features combined with accelerated and/or asynchronous emotional development are correlated to astonishment with oneself, disquietude with oneself, and dissatisfaction with oneself (Level III dynamisms). The developmental potential of an individual demonstrating dynamisms (higher-level multiple overexcitabilities) can be both ascending and chaotic $[61,113,114]$.

Feeling out-of-sync is typical of the highly-profoundly gifted population and the combined traits of multiple higher-level overexcitabilities. Laycraft $[32,61,113,114]$ showed that individuals characterized by multilevel overexcitability experience inner tensions and conflicts that create chaos in their mental structure. In this chaotic state, the rapid flow of energy links components of mental structure to coherent higher-order forms. These higher-order arrangements are developmental dynamisms, and through them the process of development proceeds to higher levels. Therefore, chaos is a necessary condition for self-organization into more complex and ordered states of mental structures in gifted individuals.

The development of the highly-profoundly gifted student is radically advanced, accelerated, and/or asynchronous compared to that of their chronological-age peers, as acknowledged by the Columbus Group [69]. To the untrained eye, this emotional development may seem immature at times, while at other times, the interperspective emotional development may seem exceptional. This is the nature of asynchronous development, often descriptive of the highly-profoundly gifted child [63]. Similarly, chaos, the corresponding nature of asynchronous development is often descriptive of overexcitabilities and the necessary condition for self-organization into more complex and ordered states of mental structures of gifted individuals $[61,113,114]$. When the holistic, advanced, and asynchronous development of the child is considered, the chaotic tendency is better understood as typical of this population.

Highly-profoundly gifted individuals tend to lean toward introversion [43]. While overexcitabilities are often misunderstood as being outwardly expressed, in actuality, due to their sensitive, intense natures, overexcitabilities can more often be inwardly expressed [43]. Similar to multifaceted, accelerated, and asynchronous emotional development, introversion is correlated to astonishment with oneself, disquietude with oneself, and dissatisfaction with oneself (Level III dynamisms), and subject-object in one-self, self-awareness, inner psychic transformation, and self-control (Level IV dynamisms; Table 5).

Cognitive characteristics, behaviors, and development: Hollingworth [2], as well as her contemporary Terman [1] and later Gross [3] substantiated an early ability and love of reading as the most common developmental milestone and characteristic of profoundly gifted children. Similarly, a common trait of intellectual overexcitability is frequent and sustained reading [82]. This intellectual overexcitability combines with emotional overexcitability. Self-acceleration, a compulsion to learn everything, and the desire for complexity have all been reported in studies of highly-profoundly gifted children [1-3]. The intense search for knowledge is a characteristic behavior of intellectual overexcitability [82]. The compulsion to learn is intellectual overexcitability associated with Levels III and IV.

In addition, the highly-profoundly gifted are known as "rapid learners"; the speed and intensity of their learning style are also characteristic of the passion, drive, and mastery associated with intellectual overexcitability [82]. The intense speed and action associated with higher-level intellectual and other overexcitabilities are driven by psychomotor overexcit-

Table 5: Relationships between emotional characteristics of the profoundly gifted and emotional overexcitability (OE) in combination with other forms of overexcitabilities and dynamisms.

\begin{tabular}{|c|c|}
\hline Emotional characteristics of highly-profoundly gifted & Emotional overexcitability in a combination with other forms of $\mathrm{OE}$ \\
\hline Emotional sensitivity and intensity & Emotional overexcitability \\
\hline $\begin{array}{ll}\text { - } & \text { Discernment } \\
\text { - } & \text { Aesthetic } \\
\text { - } & \text { Sensitivity to other }\end{array}$ & $\begin{array}{l}\text { - } \quad \text { Level III: Emotional OE combined with intellectual OE } \\
\text { - } \quad \text { Level IV: Emotional OE combined with sensual OE } \\
\text { - } \quad \text { Level III \& IV level dynamism: Empathy }\end{array}$ \\
\hline - Acute and profound awareness & $\begin{array}{l}\text { - Level III dynamism: Feeling of inferiority toward oneself } \\
\text { - Level IV dynamisms: Self-awareness, self-control }\end{array}$ \\
\hline $\begin{array}{l}\text { - } \quad \text { Strong sense of right and wrong } \\
\text { - } \quad \text { An internal guide from within }\end{array}$ & $\begin{array}{l}\text { - } \quad \text { Level III dynamism: Positive maladjustment } \\
\text { - } \quad \text { Level IV dynamism: Third factor }\end{array}$ \\
\hline $\begin{array}{l}\text { - Multifaceted, accelerated, and asynchronous } \\
\text { emotional development }\end{array}$ & $\begin{array}{l}\text { - Level III dynamisms: Astonishment with oneself, disquietude } \\
\text { with oneself, dissatisfaction with oneself (chaotic state) }\end{array}$ \\
\hline - Introversion & $\begin{array}{l}\text { - Level III dynamisms as above and } \\
\text { - Level IV dynamisms: Subject-object in oneself, self-awareness } \\
\text { inner psychic transformation, self control }\end{array}$ \\
\hline
\end{tabular}


Citation: Wood VR, Laycraft KC (2020) How Can We Better Understand, Identify, and Support Highly Gifted and Profoundly Gifted Students? A Literature Review of the Psychological Development of Highly-Profoundly Gifted Individuals and Overexcitabilities. Ann Cogn Sci 4(1):143-165

ability. Perspective insights and the ability to skip steps have been commonly reported in studies of highly-profoundly gifted children $[12,44,66]$. These behaviors are characteristic of intellectual overexcitability at Levels III and IV. The ability to engage with different perspectives and the ability to intuit can also involve sensual, imaginational, emotional, or psychomotor overexcitability, or a combination thereof, depending on the scope and context [51].

The highly-profoundly gifted's divergent thinking capabilities, the ability to see patterns, and the ability to comprehend the abstract by simplifying are distinctive traits $[3,12,44]$. These traits are also characteristic of intellectual and imaginational overexcitabilities [82], more specifically of intellectual overexcitability Level IV combined with imaginational overexcitability. In their longitudinal studies of highly-profoundly gifted children, Hollingworth [2] and Gross [3] both found deep reflective thinking: The need to ponder, contemplate, and make sense of things, the universe, and the self. This innate push for understanding, thoughtful consideration, and self-reflection also described a combination of multiple, if not all, overexcitabilities and corresponding dynamisms $[21,51,80]$ (Table 6).

Altruistic characteristics, behaviors, and development: The profoundly gifted child's need to ponder, contemplate, and sit still in silence has been extensively reported in the literature, along with an inquisitive questioning mind, high moral values, and a deep appreciation and connection to the human spirit $[2,3,23,40,43,71]$. The need to contemplate and sit in silence are related to an increasing need for reflection, meditation, and contemplation (Level III) and solitude becoming the necessary condition for developing higher dynamisms (Level IV). An inquisitive questioning mind is related to extensive, universal, and multilevel intellectual interests (Level IV) and the desire to be objective in understanding the hierarchy of values (Level IV). A deep appreciation and connection to the human spirit is related to mediation and contemplation and ecstasy toward the spiritual dimension (Level IV). The overall unique and distinguishing altruistic development is related to development of altruistic feelings based on increasing awareness (Level III) and formation of altruistic attitudes according to one's own (Level IV).

These unique and distinctive altruistic characteristics, behaviors, and development of the highly-profoundly gifted are synonymous with the typical growth of higher developmental potential found in the combination of multiple higher-level overexcitabilities. Greater-than-typical sensitivity, intensity, and awareness are all activated elements of the altruistic development evident in highly-profoundly gifted children and adolescents, just as the same elements are reflected in the descriptive flux and movement of overexcitabilities $[20,51,87]$ (Table 7) .

\section{Conclusions}

As discussed and shown in Table 4, Table 5, and Table

Table 6: Relationships between cognitive characteristics of the profoundly gifted and intellectual overexcitability (OE).

\begin{tabular}{|c|c|}
\hline Cognitive characteristics of highly-profoundly gifted & Intellectual overexcitability in a combined with other forms of $\mathrm{OE}$ \\
\hline - An early ability and love of reading & - Intellectual OE combined with Emotional OE \\
\hline $\begin{array}{l}\text { - } \quad \text { compulsion to learn } \\
\text { - } \quad \text { The desire for complexity }\end{array}$ & $\begin{array}{ll}\text { - } & \text { Intellectual OE on levels III and IV } \\
\text { - } & \text { Intellectual OE on level IV }\end{array}$ \\
\hline $\begin{array}{l}\text { - } \quad \text { Perspective insights } \\
\text { - } \quad \text { The ability to skip steps }\end{array}$ & - Intellectual OE on levels III and IV \\
\hline - $\quad$ Divergent thinking capabilities & - Intellectual OE on level IV \\
\hline $\begin{array}{l}\text { - The ability to see patterns and } \\
\text { - The ability to comprehend the abstract }\end{array}$ & - Intellectual OE on level IV \\
\hline
\end{tabular}

Table 7: Correlations between altruistic characteristics of the profoundly gifted and overexcitabilities (OEs).

\begin{tabular}{|c|c|}
\hline Altruistic characteristic of the highly-profoundly gifted & Five forms of overexcitability $\mathrm{OE}$ \\
\hline - The need to contemplate and sit in silence & $\begin{array}{l}\text { - Level III: Increasing need for reflection, meditation, and } \\
\text { contemplation } \\
\text { - Level IV: Solitude becomes the necessary condition for } \\
\text { developing higher dynamisms }\end{array}$ \\
\hline - An inquisitive questioning of the mind & $\begin{array}{l}\text { - Level IV: Extensive, universal, and multilevel intellectual interest } \\
\text { - Level IV: The desire to be objective in understanding of the } \\
\text { hierarchy of values }\end{array}$ \\
\hline $\begin{array}{l}\text { - A deep appreciation and connection to the human } \\
\text { spirit }\end{array}$ & $\begin{array}{l}\text { - Level IV: Thorough meditation and contemplation, and ecstasy } \\
\text { toward the spiritual dimension }\end{array}$ \\
\hline - The unique and distinctive altruistic development & $\begin{array}{l}\text { - Level III: Development of altruistic feelings based on an } \\
\text { increasing awareness } \\
\text { - Level IV: Formation of altruistic attitudes according to one's own } \\
\text { hierarchy of values }\end{array}$ \\
\hline
\end{tabular}


Citation: Wood VR, Laycraft KC (2020) How Can We Better Understand, Identify, and Support Highly Gifted and Profoundly Gifted Students? A Literature Review of the Psychological Development of Highly-Profoundly Gifted Individuals and Overexcitabilities. Ann Cogn Sci 4(1):143-165

6 , the characteristics of highly-profoundly gifted individuals were correlated with the higher levels of overexcitabilities and dynamisms, at Levels III and IV of positive disintegration. For example, a strong sense of right and wrong is correlated with the dynamisms of positive maladjustment, which emerges in the transition from Level III to Level IV of development, while an internal guide from within is correlated with the dynamism of the third factor, which begins its activity at the third level and becomes more active at the fourth level. Another distinctive characteristic of the highly-profoundly gifted is their unique and distinctive altruistic development. This characteristic is correlated to the development of altruism, which begins at Level III, based on increasing awareness as a result of intellectual overexcitability, and then continues through Level IV as altruistic attitudes develop according to one's own hierarchy of values. Finally, highly-profoundly gifted individuals' cognitive characteristics, such as a compulsion to learn, the desire for complexity, the ability to see patterns, and to comprehend the abstract, are correlated with intellectual overexcitability at Levels III and IV of positive disintegration, which are enhanced by other forms of overexcitabilities.

Overall, substantial correlations have been found between the social, emotional, physical, cognitive, and altruistic characteristics, behaviors and development of highly-profoundly gifted children and the higher-level overexcitabilities and developments. Heightened or greater-than-typical sensitivity, intensity, and awareness become the overarching indicators or barometers in both distinguishing qualities of profound giftedness vs. giftedness, and overexcitabilities vs. multiple higher-level overexcitabilities and dynamisms. The recognition of multiple higher-level overexcitabilities and dynamisms is the most significant finding to answer the question posed in this review. In addition, this finding offers new insights for the fields of gifted education, psychology, human development, and cognitive neuroscience.

Dynamisms differentiate the abundance of multiple higher-level overexcitabilities similar to the differentiating social, emotional, physical, cognitive and altruistic characteristics, behaviors and development found in the highly-profoundly gifted, and the levels of development identified in Dabrowski's theory of positive disintegration, compared to the lower-level overexcitabilities found in their gifted or non-gifted peers. In addition, dynamisms were correlated with the advanced, accelerated, and asynchronous development of the highly-profoundly gifted and advanced, accelerated, and chaotic development, influenced by multiple higher-level overexcitabilities of developmental potential and the theory of positive disintegration.

In conclusion, given the correlations between the social, emotional, physical, cognitive, and altruistic characteristics, behaviors and development between the highly-profoundly gifted and the differentiating correlation of multiple, higher-level overexcitabilities defined as dynamisms, the assessment of multiple, higher-level overexcitabilities and dynamisms could be an effective tool for identifying the distinguishing characteristics, behaviors, and development of highly or profoundly gifted students. Further research specific to the highly-profoundly gifted is warranted.

\section{Recommendations}

To curb the on-going misunderstanding, misidentification and misdiagnosis of highly-profoundly gifted students and the continuum of giftedness, society must first accept, recognize, and positively respond to the fundamentally different developmental and educational needs of this special population. The research summarized in this review, must be incorporated into federally mandated programs and identification tools that match the distinguishing social, emotional, physical, cognitive and altruistic characteristics, behaviors and development of highly-profoundly gifted children and adolescents.

Policy makers must mandate specific criteria and proper training for identification. This can be accomplished immediately by using a checklist of the characteristics, behaviors, and development of highly-profoundly gifted children $[10,24]$ and the overexcitabilities II questionnaire (OEQ II). Additionally, teachers, administrators and parents need training.

Additional research is the fields of gifted education, psychology, human development, neurology, and cognitive science is warranted. The development of dynamisms should be further studied and considered, especially by psychologists, in professional assessments of overexcitabilities and identification of giftedness and the highly-profoundly gifted population. Researchers should focus on the development of assessment tools to identify dynamisms, and multiple, higher-level overexcitabilities, potentially enabling better identification of overexcitabilities at the higher levels and the highly-profoundly gifted population.

Dissemination of this review through education outreach channels and professional development is essential. Teachers, administrators, parents, counselors, psychologists and pediatricians need training, by qualified professionals, to be able to properly identify the unique characteristics, behaviors, and development typical of this population. Together, we need to inclusively understand, identify, and promote the positive growth and well-being of the highly-profoundly gifted population and the developmental potential in all of us and in generations to come.

\section{Acknowledgments}

We are grateful to the Board of Directors of the International Gifted Consortium (IGC), Research Center for the Highly-Profoundly Gifted for their dedication of time and insights into the mission. We thank the IGC Contributors for their contributions and Christine Evans, Douglas Evans, and Adele Grosso for their feedback on and proofreading of the manuscript. We are also grateful to Lorraine Bouchard for her review of the paper.

\section{Funding}

This research did not receive any specific grant or funding from public agencies or the commercial or not-for-profit sectors.

\section{Declarations of Interest}

None. 
Citation: Wood VR, Laycraft KC (2020) How Can We Better Understand, Identify, and Support Highly Gifted and Profoundly Gifted Students? A Literature Review of the Psychological Development of Highly-Profoundly Gifted Individuals and Overexcitabilities. Ann Cogn Sci 4(1):143-165

\section{References}

1. Terman LM (1925) Mental and physical traits of a thousand gifted children: Genetic studies of genius. Stanford University Press, Stanford, California, 1.

2. Hollingworth LS (1942) Children above 180 IQ (Stanford-Binet): Origin and development. Yonkers-on-Hudson, World Book Company, NY.

3. Gross MUM (2004) Exceptionally gifted children. (2 $2^{\text {nd }}$ edn), Routledge Falmer, New York, NY.

4. (2016) No child is just born gifted: Creating and developing potential. The Thomas B Fordham Institute.

5. Dąbrowski K (1972) Psychoneurosis is not an illness. Gryf Publications Ltd, London.

6. Steenbergen-Hu S (2017) How exactly overexcitability relates to giftedness: A fine-grained look via findings of a new meta-analysis. NAGC Conceptual Foundations Network Newsletter, 44-49.

7. Webb JT, Amend ER, Beljan P, et al. (2016) Mis-diagnosis and dual diagnosis of gifted children: Gifted and LD, ADHD, OCD, Oppositional defiant disorder ( $2^{\text {nd }}$ edn), Distributed by ERIC Clearinghouse.

8. Silverman LK (1991) Leta Hollingworth's educational principles for the gifted. Satorian, Nebraska Association for Gifted Children Journal 6: 11-17.

9. Von Karolyi C (2001) Issue awareness, emotional intensity, and altruistic intent in young highly gifted children: Do the claims hold up? Retrieved from ProQuest dissertations and theses.

10. Schultz RA (2018) Recognizing the outliers: Behaviors and tendencies of the profoundly gifted learner in mixed-ability classrooms. Roeper Review 40: 191-196.

11. Clark B (1990) Giftedness and the gifted: What's it all about? ERIC Clearinghouse on Handicapped and Gifted Children.

12. Silverman LK (1989) The highly gifted. In: J Feldhusen, J Van Tassel-Baska, K Seeley, Excellence in educating the gifted. (edn), Denver, CO, Love, 71-83.

13. Marland SP Jr (1972) Education of the gifted and talented: Report to the congress of the United States by the U.S. Government Printing Office, Washington, DC, U.S.

14. Kristiansen-Hagne S (1998) Using Dabrowski's overexcitabilities to identify gifted students and augment their gifted potential. Retrieved from ProQuest Dissertations and Theses.

15. Janos PM, Robinson NM (1985) Psychosocial development in intellectually gifted children. In: F Jolly JL, Robins JH (2016) After the Marland report: Four decades of progress? Journal for the Education of the Gifted 39: 1-19.

16. Falk RF, Miller NB (2009) Building firm foundations: Research and assessments. In: S Daniels, Feldman DH (1993) Children prodigies: A distinct form of giftedness. Gifted Child Quarterly 37: 188-193.

17. Colangelo N (2005) In Appreciation: Julian Stanley. APS Association for Psychological Science.

18. Bernstein BO, Lubinski D, Benbow CP (2019) Psychological constellations assessed at age 13 predict distinct forms of eminence 35 years later. Psychological Science 30: 444-454.

19. Harrison JK, Lubinski D, Benbow CP (2013) Who rises to the top? Early indicators. Psychol Sci 24: 648-659.
20. Makel MC, Kell HJ, Lubinski D, et al. (2016) When lightning strikes twice: Profoundly gifted, profoundly accomplished. Psychol Sci 27: 1004-1018.

21. Piechowski MM (1979) Developmental potential. In: N Colangelo, RT Zaffrann, New voices in counseling the gifted. (edn), Dubuque, IA: Kendall/Hunt, 25-57.

22. Jacob K (1988) Javits gifted and talented students education act.

23. Silverman LK (1994) The moral sensitivity of gifted children and the evolution of society. Roeper Review 17: 110-116.

24. Asynchronous development. National Association for Gifted Children.

25. Definition and rationale for gifted education. National Association for Gifted Children.

26. Clark B (2008) Growing up gifted. ( $7^{\text {th }}$ edn), Merrill Publishing Co, Columbus, $\mathrm{OH}$.

27. IGC, Research Center for the Highly-Profoundly Gifted (2019) Over-excitabilities: Giftedness through the eyes of the highly-profoundly gifted. Paper presented at the AAGT conference, Phoenix, Arizona.

28. Gross MUM (2000) Exceptionally and profoundly gifted students: An underserved population. Understanding Our Gifted 12: 3-9.

29. Tolan SS, Wallace B, Shaughnessy MF (2018) The value and importance of mindfulness for the highly to profoundly gifted child. Gifted Education International 34: 193-202.

30. Burks BS, Jensen DW, Terman LM (1930) Genetic studies of genius: The promise of youth. University Press, Stanford, Stanford, CA.

31. Jackson PS (1998) Bright star-black sky: A phenomenological study of depression as a window into the psyche of the gifted adolescent. Roeper Review 20: 215-221.

32. Laycraft KC (2012) The development of creativity: A study of creative adolescents and young adults. University of Calgary, Calgary, Alberta.

33. Sheldon $P(1959)$ Isolation as a characteristic of highly gifted children. Journal of Educational Sociology 32: 215-221.

34. Janos PM (1983) The psychological vulnerabilities of children of very superior intellectual ability. Ohio State University.

35. Shaklee B (2009) Highly gifted. In: B Kerr, Encyclopedia of giftedness, creativity, and talent. (edn), SAGE Publications, Inc. Thousand Oaks, CA, 416-416.

36. Gross M (1993) Exceptionally gifted children. London, New York, Routledge.

37. Gross MUM (1994) Radical acceleration: Responding to academic and social needs of extremely gifted adolescents. Journal of Secondary Gifted Education 5: 27-34.

38. Hollingworth LS (1926) Gifted children. Their nature and nurture. New York, Macmillan.

39. Neihart M, National Association for Gifted Children (2002) The social and emotional development of gifted children: What do we know? Prufrock Press, Texas.

40. Potts JA (2019) Profoundly gifted students' perception of virtual classrooms. Gifted Child Quarterly 63: 58-80.

41. Neville CS, Piechowski MM, Tolan SS (2013) Off the charts: Asynchrony and the gifted child. Royal Fireworks Press, Unionville, NY. 
Citation: Wood VR, Laycraft KC (2020) How Can We Better Understand, Identify, and Support Highly Gifted and Profoundly Gifted Students? A Literature Review of the Psychological Development of Highly-Profoundly Gifted Individuals and Overexcitabilities. Ann Cogn Sci 4(1):143-165

42. Freeman J (1983) Emotional problems of the gifted child. Journal of Child Psychology and Psychiatry 24: 481-485.

43. Silverman LK (1993) Counseling the gifted and talented. Love, Denver, CO.

44. Lovecky DV (2004) Different minds: Gifted children with AD/HD, Asperger syndrome, and other learning deficits. Jessica Kingsley Publishers Ltd, London.

45. Piechowski MM (2013) "A bird who can soar": Overexcitabilities in the gifted. In: C Neville, MM Piechowski, SS Tolan, Off the charts: Asynchrony and the gifted child. (edn), Royal Fireworks Press, Unionville, NY, 99-122.

46. Silverman LK (1983) Personality development: The pursuit of excellence. Journal for the Education of the Gifted, 6: 5-19.

47. Webb J, Meckstroth E, Tolan S (1982) Guiding the gifted child: A practical source for parents and teachers. Ohio Psychology Pub. Co, Columbus, Ohio.

48. Roeper A (1982) How the gifted cope with their emotions. Roeper Review 5: 21-24.

49. Jackson PS, Peterson J (2003) Depressive disorder in highly gifted adolescents. Journal of Secondary Gifted Education 14: 175-186.

50. Silverman LK, Kearney K (1989) Parents of the extraordinary gifted. Advanced Development 1: 41-56.

51. Piechowski MM (1991) Emotional development and emotional giftedness. In: N Colangelo, GA Davis (edn), Handbook of gifted education, MA: Allyn \& Bacon, Boston, 285-306.

52. Saricam H, Sahin SH (2015) The relationship between the environmental awareness, environmental attitude, curiosity and exploration in highly gifted students: structural equation modeling. Educational Process: International Journal 4: 7-17.

53. Whitmore PG (1980) Straw men fail criterion tests. NSPI Journal 14: $32-34$

54. Tannenbaum AJ (1983) Gifted children. New York Macmillan.

55. Piechowski M (2002) Experiencing in a higher key: Dabrowski's theory of and for the gifted. Gifted Education Communicator 33: 31-36.

56. Mahoney AS (1998) In search of gifted identity: From abstract concept to workable counseling constructs. Roeper Review 20: 222-226.

57. Goriounova NA, Mansvelder HD (2019) Genes, cells and brain areas of intelligence. Front Hum Neurosci 13: 44.

58. Vaivre-Douret L (2011) Developmental and cognitive characteristics of "high-level potentialities" (highly gifted) children. Int J Pediatr 2011: 420297.

59. Alexander JE, O'Boyle MW, Benbow CP (1996) Developmentally advanced EEG alpha power in gifted male and female adolescents. Int J Psychophysiol 23: 25-31.

60. O'Boyle M (2008) Mathematically gifted Children: Developmental brain characteristics and their prognosis for well-being. Roeper Review 30: 181-186.

61. Laycraft KC (2011) Theory of positive disintegration as a model of adolescent development. Nonlinear Dynamics, Psychology, and Life Sciences 15: 29-52.

62. Benbow CP (1986) Physiological correlates of extreme intellectual precocity. Neuropsychologia 24: 719-725.

63. Rogers K, Silverman L (1997) The construct of asynchrony. Paper presented at the $44^{\text {th }}$ annual conference of the National Association for Gifted Children, Little Rock, Arkansas.

64. Lagos LM (2013) The physiologically gifted child. Biofeedback 31: 62-65.

65. Siegle D (2007) Gifted children's bill of rights.

66. Morelock MJ (1995) The profoundly gifted child in family context.

67. Harvey SJ (n.d), High, exceptional and profound giftedness.

68. Lovecky DV (1994) Exceptionally gifted children: Different minds. Roeper Review 17: 116-120.

69. Morelock MJ (1992) Giftedness: The view from within. Understanding Our Gifted 4: 11-15.

70. Lovecky DV (1997) Identity development in gifted children: Moral Sensitivity. Roper Review 20: 90-94.

71. Roeper A (1988) Should educators of the gifted and talented be concerned with world issues? Roeper Review 11: 12-13.

72. Howard-Hamilton M (1994) An assessment of moral development in gifted adolescents. Roeper Review 17: 57-59.

73. Piechowski MM (2003) From william james to masloe and dabrowski: Excitability of character and self-actualization. In: D Ambrose, LM Cohen, AJ Tannenbaum, Creative intelligence: Toward a theoretic integration. Hampton Press, Cress Kill, New Jersey, 283-322.

74. Sisk D (1982) Caring and sharing: Moral development of gifted students. The Elementary School Journal 82: 221-229.

75. (1899) States of over-excitability, hyper-sensitiveness, and mental explosiveness in children. The Lancet 154: 292.

76. Dabrowski K (1964) Positive disintegration.

77. Dabrowski K (1996) Multilevelness of emotional and instinctive functions. Lublin: Scientific Society of the Catholic University of Lublin.

78. Colangelo N, Davis GA (1991) Handbook of gifted education. (3 $3^{\text {rd }}$ edn), Allyn \& Bacon publications, Boston, Massachusetts.

79. Dąbrowski K, Kawczak A, Piechowski M (1970) Mental growth through positive disintegration. Gryf Publication Ltd, London.

80. Dąbrowski K, Piechowski MM (1977) Theory of levels of emotional development: Multilevelness and positive disintegration. Dabor Science Publications, New York, 1.

81. Piechowski MM (1999) Overexcitabilities. In: M Runco, S Pritzker, Encyclopedia of creativity. (edn) Academic Press, San Diego, CA, 2: 325-334.

82. Daniels S, Piechowski MM (2009) Living with intensity, Great Potential Press, Arizona.

83. Lind S (2011) Overexcitabilities and the gifted.

84. Piechowski MM (1978) Self-actualization as a developmental structure: A profile of Antoine de Saint-Exupéry. Genetic Psychology Monographs 97: 181-242.

85. Piechowski MM (2009) Peace pilgrim, exemplar of level V, Roeper Review 31: 103-112.

86. Dąbrowski K (1973) The dynamics of concepts, Gryf Publications Ltd, London.

87. Dąbrowski K, Piechowski MM (1977) Theory of levels of emotional development. From primary integration to self-actualization, Dabor Science Publications, New York, 2. 
Citation: Wood VR, Laycraft KC (2020) How Can We Better Understand, Identify, and Support Highly Gifted and Profoundly Gifted Students? A Literature Review of the Psychological Development of Highly-Profoundly Gifted Individuals and Overexcitabilities. Ann Cogn Sci 4(1):143-165

88. Damasio A (2003) Looking for spinoza: Joy, Sorrow, and the feeling brain. A Harvest Book Harcourt, Inc, New York.

89. Tangney JP, Miller RS, Flicker L, et al. (1996) Are shame, guilt, and embarrassment distinct emotions? Journal of Personality and Social Psychology 70: 1256-1269.

90. Keltner D, Buswell BN (1997) Embarrassment: Its distinct form and appeasement functions. Psychological Bulletin 122: 250270.

91. Harter S (1999) The construction of the self. A developmental perspective. The Guilford Press, New York.

92. Kaminski Battaglia MM (2002) A hermeneutic historical study of Kazimierz Dabrowski and his theory of positive disintegration. ProQuest Dissertations and Theses.

93. Lysy KZ, Piechowski MM (1983) Personal growth: An empirical study using Jungian and Dabrowskian measures. Genetic Psychology Monographs 108: 267-320.

94. Falk RF, Lind S, Miller NB, et al. (1999) The over excitability questionnaire-two (OEQII): Manual, scoring system, and questionnaire. Institute for the Study of Advanced Development, Denver, USA.

95. Daniels S (2009) Highly gifted, highly sensitive, and highly intense. Gifted Education Communicator 40: 19-24.

96. Jackson PS, Moyle VF, Piechowksi MM (2009) Emotional life and psychotherapy of the gifted in light of Dabrowski's theory. In: LV Shavinina, International handbook on giftedness. Springer, Dordrecht, 437-465.

97. Silverman LK, Ellsworth B (1981) The theory of positive disintegration and its implication for giftedness. In: N Duda, Theory of positive disintegration: Proceedings of the third international conference. University of Miami, Miami, FI, USA, 179-194.

98. Ackerman C (1996) Identifying gifted adolescents using personality characteristics: Dabrowski's overexcitabilities. Roeper Review 19: 229-236.

99. Mendaglio S, Tillier W (2006) Dabrowski's theory of positive disintegration and giftedness: Overexcitability research findings. Journal for the Education of the gifted 30: 68-87.

100. Mendaglio S (2012) Overecitabilities and giftedness research: A call for a paradigm shift. Journal for the Education of the Gifted 35: 207-219.
101. Chang HJ, Kuo C (2013) Overexcitabilities: Empirical studies and application. Learning and Individual Differences 23: 53-63.

102. Gallagher S (1985) A comparison of the concept of overexcitabilities with measures of creativity and school achievement in sixth-grade students, Roeper Review 8: 115-119.

103. Harrison G, Van Haneghan J (2011) The gifted and the shadow of the night: Dabrowski's overexcitabilities and their correlation to insomnia, death anxiety, and fear of the unknown. Journal for the Education of the Gifted 34: 669-697.

104. Piechowski MM, Colangelo N (1984) Developmental potential of the gifted. Gifted Child Quarterly 28: 80-88.

105. Tieso C (2007) Patterns of overexcitabilities in identified gifted students and their parents: A hierarchical model. Gifted Child Quarterly 51: 11-22.

106. Tucker B, Hafenstein N (1997) Psychological intensities in young gifted children. Gifted child Quarterly 41: 66-75.

107. Bouchard LL (2004) An instrument for the measure of Dabrowskian overexcitabilities to identify gifted elementary students. Gifted Child Quarterly 48: 339-350.

108. Winker D, Voight A (2016) Giftedness and overexcitability: Investigating the relationship using meta-analysis. Gifted Child Quarterly 60: 243-257.

109. Kuo CC, HJ, Chang YP, et al. (2012) Psychological traits and brain structures of mathematically/scientifically senior high school talented students. Bulletin of Educational Psychology 43: 805832.

110. Karpinski RI, Kinase Kolb AM, Tetreault NA, et al. (2018) High intelligence: A risk factor for psychological and physiological overexcitabilities. Intelligence 66: 8-23.

111. Piechowski MM (1986) The concept of developmental potential. Roeper Review 8: 190-197.

112. Piechowski MM (2006) "Mellow out," they say. If I only could: Intensities and sensitivities of the young and bright. Yunasa Books, Madison, WI.

113. Laycraft K (2009) Positive maladjustment as a transition from chaos to order. Roeper Review 31: 113-122.

114. Laycraft KC (2017) Positive disintegration as a process of symmetry breaking. Nonlinear Dynamics Psychol Life Sci 21: 143158.

DOI: $10.36959 / 447 / 348$ 